\title{
Lignocellulosic and algal biomass for bio-crude production using hydrothermal liquefaction: Conversion techniques, mechanism and process conditions: A review
}

\author{
Chitra Devi Venkatachalam ${ }^{1 \dagger}$, Sathish Raam Ravichandran ${ }^{2}$, Mothil Sengottian ${ }^{2}$ \\ ${ }^{1}$ Department of Food Technology, Kongu Engineering College, Perundurai, Erode, Tamilnadu, India - 638060 \\ ${ }^{2}$ Department of Chemical Engineering, Kongu Engineering College, Perundurai, Erode, Tamilnadu, India - 638060
}

\begin{abstract}
Thermochemical conversion is an effective process in production of biocrude. It mainly includes techniques such as torrefaction, liquefaction, gasification and pyrolysis in which Hydrothermal Liquefaction (HTL) has the potential to produce significant energy resource. Algae, one of the third-generation feedstocks is placed in the top order for production of bio-oil compared to the first and second-generation feedstock, as the algae can get multiplied in shorter time with the uptake of greenhouse gases. In HTL, the subcritical water helps the biomass to undergo thermal depolymerisation and produce various chemicals such as nitrogenates, alkanes, phenolics, esters, etc. The produced "biocrude" or "bio-oil" may be further upgraded into value-added chemicals and fuels. In addition, the bio-gas and bio-char are also synthesized as by-products. This review provides an overview of different routes available for thermochemical conversion of biomass. It also provides an insight on the operating parameters such as temperature, pressure, dosage of catalyst and solvent for lignocellulosic and algal biomass under HTL environment. In extent, the article covers the conversion mechanism for these two feedstocks and also the effects of the operating parameters on the yield of biocrude are studied in detail.
\end{abstract}

Keywords: Algae biomass, Biofuel, Hydrothermal liquefaction, Lignocellulosic, Thermochemical conversion

\section{Introduction}

The world's current population is about 7.7 billion and it is projected to reach 8 billion in next future. It is said that the world's population is increasing at the rate of $1 \%$ per year [1]. The exponential growth of population creates scarcity for food and energy. As the population increases, in recent years, the utilization of crude derivatives is significantly increasing as it is one of the main sources of transportation (both people and goods). Earlier, the energy is recovered from non-petroleum derivatives sources such as animal-derivatives like oil, fat, etc., coal, and wood. According to Energy Information Administration (EIA), that world's liquid fuel consumption is 101 million barrels per day during 2019 to 2020 . It is also predicted that the consumption rate will raise by $2.5 \%$ in forthcoming years. The conventional way of producing energy comes from burning fossil fuel. This large mass of energy can't be recovered from conven- tional resources and it made as a challenging situation for industry. This challenge attracts researchers, entrepreneurs and many others to focus on renewable resources for energy production. The organic substances are the group of carbon and hydrogen molecules which varies with location and feedstocks. The remains of plants and animals (organic matter) when buried beneath the earth's surface at suitable conditions like temperature, pressure and influence of micro-organism forms out to be the "fossils" [2]. The conventional depolymerisation activity is carried out to break the organic matters in fine materials. Further, this process takes millions of years to turn these organics into solid, liquid and gaseous fuel, which has an ever-growing demand. To meet such demands an advanced depolymerisation technology is adopted in the recent era. But the problem is with this technology is that they produce the major product (say gas) along with minor product (liquid or solid). The composition can vary with respected to the severity of the environ-
This is an Open Access article distributed under the terms of the Creative Commons Attribution Non-Commercial License (http://creativecommons.org/licenses/by-nc/3.0/) which permits unrestricted non-commercial use, distribution, and reproduction in any medium, provided the original work is properly cited.

Copyright (C) 2022 Korean Society of Environmental Engineers
Received October 06, 2020 Accepted December 28, 2020

${ }^{\dagger}$ Corresponding author

E-mail: erchitrasuresh@gmail.com

Tel: +91-98659-04404

ORCID: 0000-0001-8510-2249 
ment inside the reactor. Many advances or modification were made to improve the yield of the desired product however, the formation of by-products cannot be minimized in larger extent. One of the promising areas is Thermal Depolymerisation Process (TDP) in which organic substances are thermally decomposes at high temperatures and pressure.

Different conversion techniques are available for depolymerisation of biomasses, such as chemical, thermochemical, biochemical and electrochemical conversions. Based on the nature of feedstock it is categorised as wet biomass and dry biomass based on the amount of moisture present in the feed on a weight basis. Dry biomass is the widely used feedstock in past decades since the energy spends for pre-processing the biomass is not required. But now the wet biomass can also be directly used instead of dry since the moisture helps in enhancing the biofuel formation [3]. This wet biomass can be processed in different technologies such as hydrothermal carbonization (HTC), hydrothermal liquefaction (HTL) and hydrothermal gasification (HTG) yet hydrothermal liquefaction is considered as the high possible conversion route for the production of crudes [4].

\section{Thermochemical Conversion Schemes of} Biomass

The world market needs a sustainable energy production route since it doesn't create a risk for the production of alternate fuel. Such energetic conversion route for the depolymerisation activity is "Thermochemical conversion". Thermochemical conversion is the technique for conversion of biomass in to value added products or producing fine chemicals. Compared to others, these techniques are fast, less specific on feedstocks and desirability to produce high value-added products like phenolics, acetic acid, furans, malic acid, lactic acid and hence it is considered as the efficient method $[5,6]$. The facility of finding biofuel in terms of gas, oil or solid completely depends on its process condition to be followed. Based on these required process conditions and feed condition the different routes of biomass conversion may be implemented. It is be classified into two categories: dry (nonaqueous) method and wet (hydrothermal) method. Fig. 1 shows the common conversion technique of various thermochemical routes for the production of biocrude and value-added products.

In dry (nonaqueous) method, the process can be placed in the sequential order. In this, the temperature increases and follows, at initial, structure decomposition on the biomass. Further, it occurs in the region below $300^{\circ} \mathrm{C}$ where the volatiles are released from the biomass - Torrefaction. The biomass is the next degraded to condensable vapours and it happens in the temperature interval of $300^{\circ} \mathrm{C}$ to $700^{\circ} \mathrm{C}$, close to the surface of the biomass where it gets to the form of vapours - Carbonization and pyrolysis. Finally, the close range between $700^{\circ} \mathrm{C}$ and $900^{\circ} \mathrm{C}$ the vapours are gasified into combustible gases - Gasification. In hydrothermal methods are not a sequential process and hence for Hydrothermal Carbonization (HTC) at mild temperature below $220^{\circ} \mathrm{C}$ with autogenous pressure condition, solid products (commonly called "Biochar") are formed as the product. In Hydrothermal Liquefaction
(HTL) process, under mild temperature of $300^{\circ} \mathrm{C}$ to $400^{\circ} \mathrm{C}$ and high pressure up to 200bar, liquid (commonly termed as "bio-oil") hydrocarbons are formed as the main product. At elevated temperature (between $400^{\circ} \mathrm{C} \mathrm{\&} 700^{\circ} \mathrm{C}$ ) and pressure (between 250bar to 400bar), the liquid (water) tends to behave as the supercritical fluid which helps to increase the formation of gaseous products (referred as "Biogas") and the process is termed as Hydrothermal Gasification (HTG) [7-12].

\subsection{Dry Thermochemical Conversion}

\subsubsection{Torrefaction}

Torrefaction is referred as roasting, thermal pre-treatment, mild pyrolysis and even sometimes as densification process [13]. Torrefaction is mainly referred as the pre-treatment method, it severs for two main reasons (i.) to breakdown the cell wall, (ii.) to modify the structure of intercellular carbohydrates in algae [14]. Where in case of lignocellulosic biomass, the diverged composition of lignocellulose biomass makes them very complex and resistant to degrade. Generally, torrefaction in upgradation refers to thermal degradation of biomass in to value added products operated at inert atmospheric condition and hence biomass is thermally decomposed into the biochar in the temperature 200 to 300 for quite a few hours. Based on the temperature range it is categorised into light (200-235), mild (235-275), and severe (275-300) [15]. Using torrefaction, the property of biomass can be improved in larger extent (i.) reducing the presence of moisture, (ii.) intensification in energy density, (iii.) reduction in the $\mathrm{O} / \mathrm{C}$ ratio, (iv.) increase in heating value, (v.) improved ignitability and reactivity of the processed fuel [16].

Unlike coal whose high heating value (HHV) is 25 to $35 \mathrm{MJ}$ $\mathrm{kg}^{-1}$, the produced biochar from torrefaction is found to have lower $\mathrm{HHV}$ that lies between 14 to $22 \mathrm{MJ} \mathrm{kg}^{-1}$ [17] for lignocellulosic and 13 to $24 \mathrm{MJ} \mathrm{kg}^{-1}$ for algal biomass [18]. The biochar contains about $90 \%$ of energy distribution at 210 in hemicellulose, $98 \%$, $97 \%$ and $96 \%$ of energy distribution at 210, 240, 270 in cellulose and $91 \%$ of energy distribution at 210 in lignin [19]. Based on the performance and energy usage of biomass, correlations were developed that shows when Upgrading Energy Index (UEI) decreases, as the Torrefaction Severity Index (TSI) increases. From the correlations, it is understood that the variations in UEI, strongly influences the HHV of biochar [20].

As for as thermal conversion is concerned the focus is on both yield percentage and the energy supplement. Recently researches focusing on oxidation activity carried out in torrefaction of biomass is registered and it shows a higher concentration of oxygen and also shorter residence time that favours higher UEI [21]. Wei-Hsin Chen mentioned the trend for enhancement factor for HHV and solid yield in torrefaction. For any sever nonoxidative torrefaction process, the HHV enhancement factor increases in turn decreases the solid yield. In contrast, because of oxidation reaction in torrefaction both solid yield and the HHV enhancement factor decreases [22]. In lignocellulosic biomass, the presence of lignin, shows the impact on energy distribution in biochar [23].

\subsubsection{Carbonization}

The term carbonization describes the conversion of an organic materials into carbon rich or carbon-containing residue though 


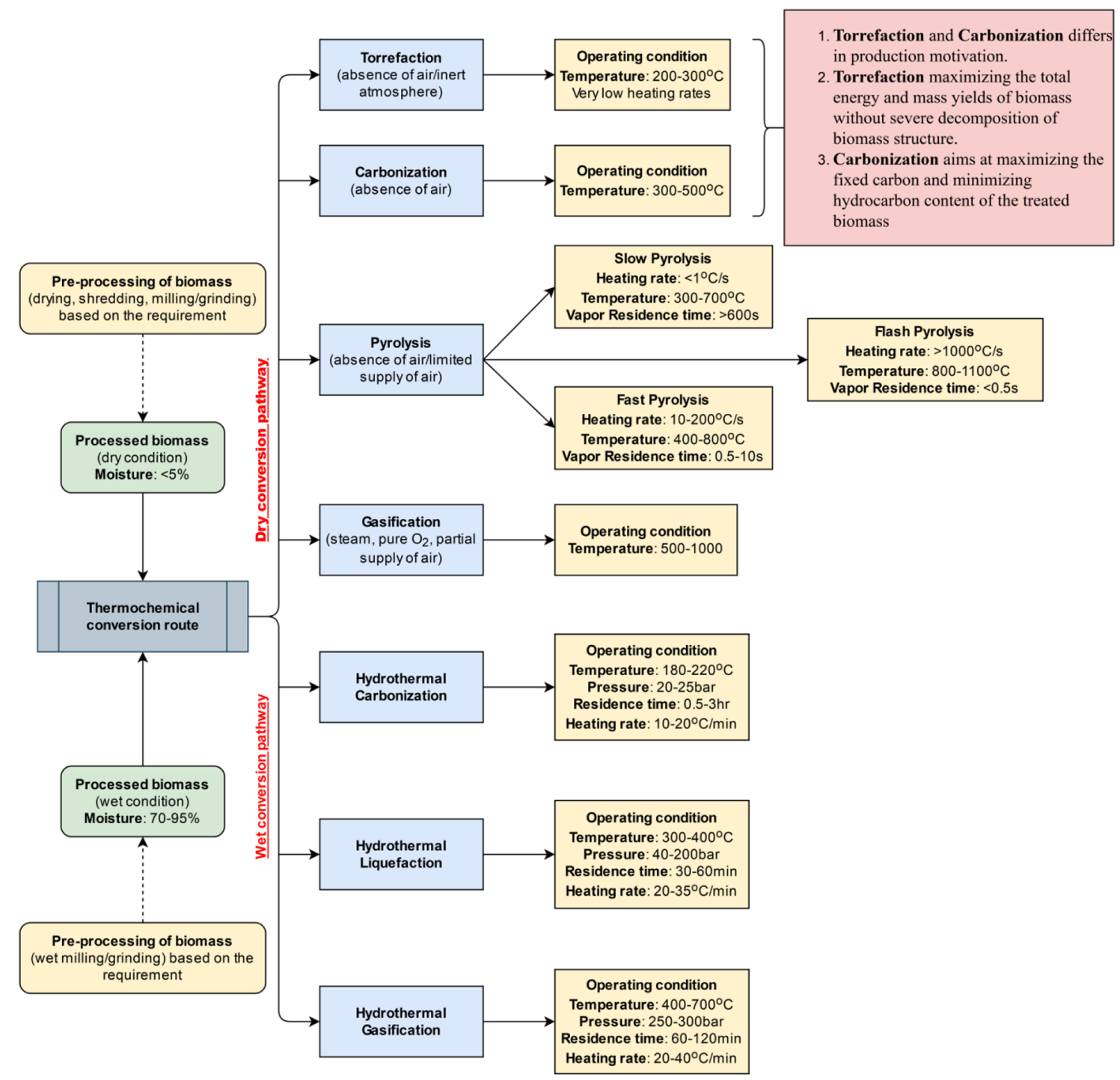

Fig. 1. Different thermochemical conversion pathway for biomass.

thermal degradation under inert atmosphere. It is identified as a complex thermochemical method as several reactions takes place simultaneously. Reactions such as dehydrogenation, condensation, hydrogen transfer and isomerization take place under 300 to 500 [24]. Carbonization and torrefaction differ in the production motive as carbonization. It aims to maximize the fixed carbon and minimize the hydrocarbon content of the treated biomass. Presently, only few literatures are available in scope of carbonization of biomass, most focus on hydrothermal carbonization. More detailed review on hydrothermal carbonization (HTC) is appended as a separate section.

\subsubsection{Pyrolysis}

Pyrolysis is one of thermal decomposition process where the organic constituents are depolymerised in absence of oxygen or at an inert atmosphere. Through pyrolysis the natural polymeric substance is broken down into volatile gases containing $\mathrm{O}^{-}$and $\mathrm{H}^{-}$form and latter gets recondensed in subsequent processes [25]. Since temperature is the base for all thermochemical pathways, pyrolysis operates between the temperature scale of 300 to 1,300 and flexible residence time (based on temperature). There are 3 different modes of pyrolysis process such as Fast Pyrolysis (FP), Slow Pyrolysis (SP) and Flash Pyrolysis (FIP) whose conditions are reported in the Fig.1. It is observed that flash pyrolysis favours bio-oil yield, followed by fast and slow pyrolysis, similarly, for both biochar and biogas slow pyrolysis favours the formation followed by fast and flash pyrolysis [26]. Other advanced types of pyrolysis like Microwave Assisted Pyrolysis (MAP), Vacuum Pyrolysis (VP), Catalytic Pyrolysis (CP), Hydropyrolysis (HP) are also cited in many publications [27-30].

Microwave Assisted Pyrolysis (MAP) draws the attention of many researchers since it is highly advantageous over other conventional pyrolysis. As in MAP, first the microwave first transfer to the core of biomass and converted into thermal energy. The thermal energy then depolymerises the biomass from inwards to outwards which 
is opposite of all conventional methods [31]. For the following reasons such as (i.) noncontact heating, (ii.) selective separation, (iii.) low thermal inertia, energy consumption, (iv.) rapid heating rate, (v.) high level of control over the process [32, 33]. Slow pyrolysis is the conventional method that was reported way long back [34] that operates under mild condition of 300 to 700 with the holdup time of several hours. Comparing FP and SP, it is observed that there is no large deviation in overall yield, but significant changes are recorded in individual percentages of char, tar and gas. As well, when the syngas production is compared at different temperatures SP displays more yield than FP. Both SF and PF shows losses but surprisingly it is within $15 \%$ for FP than SP. This loss is due to the escape of volatile compounds from the column [35].

\subsubsection{Gasification}

Gasification is the process that converts the biomass (carbonaceous material) into suitable gaseous fuels or fine chemicals. In gasification, process is taken place in 3 diverse steps: (i.) An endothermic reaction occurs in which the biomass is transformed (under the influence of temperature) into char and volatile matter, such as acetic acid $\left(\mathrm{CH}_{3} \mathrm{COOH}\right)$, methanol $\left(\mathrm{CH}_{3} \mathrm{OH}\right)$, steam and tar. (ii.) The produced char is oxidized further to form carbon dioxide $\left(\mathrm{CO}_{2}\right)$ which is an exothermic reaction. (iii.) Most part of $\mathrm{CO}_{2}$, steam, volatile matters are reduced to methane $\left(\mathrm{CH}_{4}\right)$ and carbon monoxide (CO). In some cases, the unreacted $\mathrm{CO}_{2}$ is represented as "syngas" [36]. It serves the major usage of not only for energy conversion but also important to process other fine chemicals. The conversion process is carried out between the temperature range of 500 to 1,000 and pressure $>0.1 \mathrm{MPa}$, that requires drying (moisture content \&lt 30\%) [37]. The process requires the medium such as subcritical steam, oxygen, supercritical water or a mixture of all can be considered. In both gasification and pyrolysis, the relative the $\mathrm{C} / \mathrm{H}$ ratio is always found to be in increasing trend [38]. Several kinds of literature display the proven values for gasification efficiencies (amount of carbon in gas to amount of carbon in feed) that is increased by ruthenium catalyst in gasification environment. The higher gaseous products can be achieved in the following template like elevated temperatures, low algae concentration and finally longer residence time inside the reactor [39]. Several publication report that gasification is the most hopeful technology for the production of heat, ethanol, hydrogen and electricity [40, 41].

\subsection{Wet Thermochemical Conversion}

\subsubsection{Hydrothermal carbonization}

The rapid advancement towards industrialization and the demand for renewable resources leads to development of advance conversion techniques like Hydrothermal Carbonization (HTC) for biofuel production [42, 43]. This process is considered as the energy densified process, easily friable, and more hydrophobic [44]. If biochar/biocoal/hydrochar is its main concern HTC is preferred as no energy is required for dry/pre-treating the biomass, as the moisture helps to pressurize the reactor [10]. Hydrothermal Carbonization, a category in wet thermochemical process which is favourable for wet biomasses. This process is considered as an energy intensified process at quite low temperature (180 to 220), under water pressurized condition (20 to 25 bar) speeds up the conventional of carbonization. Compared to all other wet thermochemical con- versions, HTC requires longer residence time of about 2 to $3 \mathrm{~h}$, with the moderate heating rate of 10 to 20 [45]. To avoid pyrolysis and gasification, entire biomass should be kept in submerged condition which maintains the water in subcritical state [46]. The biochar (product) for any HTC process lies between 50 and 80 wt\%, followed by $5-20 \%$ in the aqueous phase (probably water) and $2-5 \%$ biogas [47-49].

The end product from HTC is biochar followed by some non-condensable gases commonly $\mathrm{CO}_{2}$, soluble organic compounds, minerals and water [48]. Kim et al. [50] studied the characteristic of algal biomasses such as $H$. reticulatum, $C$. vulgaris and sludge to produce biochar using HTC. Trails were conducted in the temperature range of 180 to 270 with the residence time of $60 \mathrm{~min}$. It is evidently proved that 210 is optimum reaction temperature for algal biomass under HTC condition, where more energy rich solid fuels are formed. The main application of biochar obtained from HTC lies in the usage as functionalized materials for high energy storage capacity. Sometimes, the biochar finds its usage in following regions such as sorption process [51], soil enrichers [52] and even erstwhile as catalyst [53, 54].

\subsubsection{Hydrothermal liquefaction:}

HTL conversion technique is highly advantageous compared to all other thermochemical processes because it doesn't require any preliminary drying. The biomass can be used as such, once it is free from physical debris. Since pre-treatments is not necessary for liquefaction the washed wet biomass can be used directly for the conversion process. It is also evident that the biomass loading should be above $10 \%$ for economic and commercial-scale operations [55]. Several pieces of literature recorded the liquefaction temperature between 200 to 350 , with the pressure 5 to $10 \mathrm{MPa}$ and residence time between 5 to $60 \mathrm{~min}$ [56]. In recent years several attempts are made in pipeline such isothermal and fast HTL by altering the heating rate given to the biomass [57, 58]. The detailed review is made on HTL and the effect of parameters such as, feedstock composition, elemental composition, solvent polarity, catalyst, reaction time, temperature and pressure and $\mathrm{pH}$ on yield of bio-oil in the following sections. Fig. 2 shows the thermal degradation of lignocellulosic biomass and algal biomass.

\subsubsection{Hydrothermal gasification}

Hydrothermal gasification is initially portrayed as Supercritical Water Oxidation process (SCWO) to understand the decomposition of glucose in aqueous phase [59]. HTG is the process of converting biomass into gaseous products commonly referred as "biogas" (accompanied with liquid hydrocarbon - sometimes). The only contrast of HTG over conventional gasification is in the conversion process takes place with water content which help to completely and energetically efficiently biogas [60]. This promising depolymerization technology decomposes the organic materials containing high moisture above the supercritical point of water i.e temperature range between 400 to 700 with pressure 200 to 300 bar. The HTG reaction time proceeds for 60 to $120 \mathrm{~min}$ with the heating rate of 20 to $40 \mathrm{~min}$ [61].

The main advantages of the process lie in the composition of biogas produced and the yield of fuel gas which can be controlled and adjusted by reaction parameters such as temperature, pressure, 


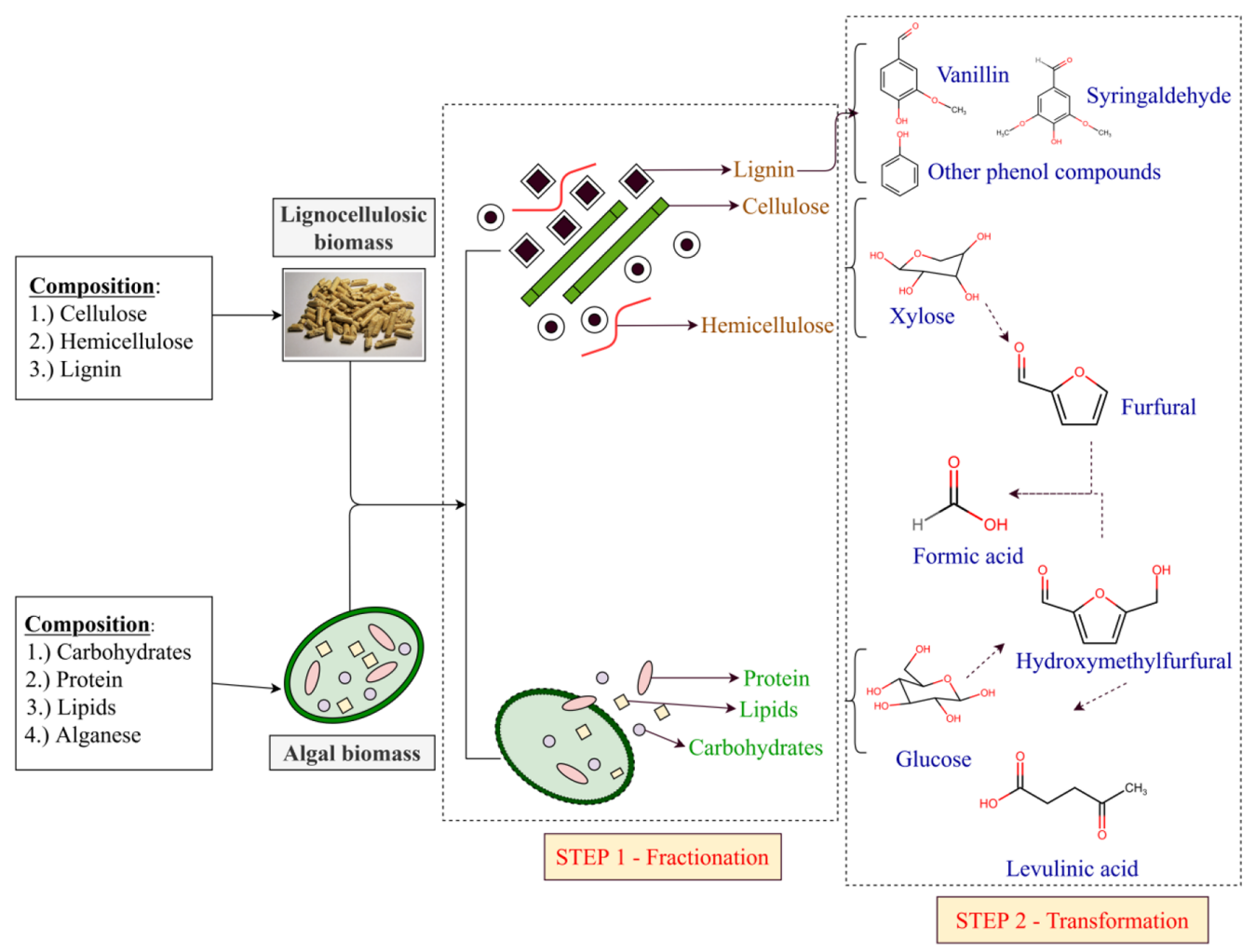

Fig. 2. Effect of thermal degradation on lignocellulosic and algal biomass.

biomass loading, feedstock composition and type of catalysts preferred [62]. In addition to the parameters inferred above, temperature is the crucial parameter as it largely affects the yield/composition of biogas is formed [63].

\section{Feedstocks}

The feedstock used to produce biofuel is generally called as "biomass". The biomass is an organic matter which is rich in carbon and some numbers of hydrogen. The biomass is defined as derivatives of wood and wood wastes, agricultural crops and the waste, aquatic plants, etc [64].

\subsection{Woody Biomass}

The biomass can be named as "lignocellulosic biomass" if they are derived from wood. India is one of the top 10 countries in the world having $23.68 \%$ that is 802,088 sq.kms of forest area. With this larger percentage of area with more than 10,000 species wood including teak, mahogany, shisham wood, oak, bamboo wood, mango, pine, maple, cherry, cedar, acacia which is used highly in the field of biofuels conversion. Most of the species are used for different purpose like food, energy crops, fuel, furnishing works etc. But still some other species are grown specifically for usage as an "energy crop". Such crops are the major source of raw material for the thermochemical processing of biomass. Wood is the hard, porous and fibrous material found in the stems and roots of trees [65]. The wood is classified into two grades as hardwoods and softwoods based on physical and chemical properties. Each part of wood consists of three basic polymers such as cellulose $\left(\mathrm{C}_{6} \mathrm{H}_{10} \mathrm{O}_{5}\right)_{n}$, hemicellulose that include xylan, glucuronoxylan, arabinoxylan, glucomannan, and xyloglucan $\left(\mathrm{C}_{5} \mathrm{H}_{8} \mathrm{O}_{4}\right)_{\mathrm{m}}$ and lignin $\left[\mathrm{C}_{9} \mathrm{H}_{10} \mathrm{O}_{3}\left(\mathrm{OH}_{3}\right)_{0.9-1.7}\right]_{x}$ present in bark, cambium, sapwood, heartwood, pith and foliage which is a heterogeneous material anatomically and chemically [66]. The cellulose and hemicelluloses can collectively term as holocellulose. Cellulose and hemicellulose get hydrolysed into simple sugars. Whereas lignin acts as support to cell structure and hinders the susceptibility to microbial attack during hydrolysis process [67]. The presence of these components is similar in all plants, but the composition varies between the species and also with the distinct varieties of woods which is hardwood and softwood. In general, the hardwoods such as oak, maple, cottonwood, etc., possess cellulose (43\%), hemicellulose (35\%) and other extractives with a lesser percentage of lignin (22\%). While the softwoods such as cedar, pine, redwood, etc., has cellulose (43\%), hemicellulose (28\%) and a higher percentage of lignin (29\%). Cellulose, a long-chain polysaccharide is a non-polar compound with a high degree of polymerization that is soluble in water with an increase in temperature. Hemicellulose (macromolecular substance containing 50 to 200 monomer units) is richly available heteropolysaccharides next to cellulose, which varies considerably based on the plant species. Biopolymer with complex amorphous monomer is lignin which binds the cell fibres together. As this complex monomer is thermally stable, lignin can be decomposed only at high temperatures [68]. Despite the difference in composition the interest in these polysaccharides or polymers increases due 
to its higher heating value. The Higher Heating Value (HHV) of the cellulose and hemicellulose $(17.6 \mathrm{MJ} / \mathrm{kg})$ is lower than lignin (23.3 to $26.6 \mathrm{MJ} / \mathrm{kg}$ ) due to elevated degree of oxidation [69]. Inspite lignin has large $\mathrm{HHV}$ value, the complexity lies in their reaction kinetics makes it difficult for further processing. The HHV for these polymers is calculated somewhere in the earlier works of [70] using ultimate analysis data and an empirical equation is structured for calculating the heating value of lignocellulosic biomass given by the Eq. (1),

$$
\begin{gathered}
\mathrm{HHV}=34.90 \times \mathrm{C}+117.82 \times \mathrm{H}-10.32 \times \\
\mathrm{O}-1.51 \times \mathrm{N}+10.05 \times \mathrm{S}-2.11 \times \text { Ash }
\end{gathered}
$$

From the Fig. 3 clearly shows that composition of holocellulose and lignin in percentage, based on which the complexity involved can be understand whereas Fig. 4 compares the major constituents of lignocellulosic biomass. So, in general, about $42 \%$ cellulose, $27 \%$ hemicelluloses, $28 \%$ lignin, and 3\% organic extractives are present in softwood. In case of hardwood, $45 \%$ cellulose, $30 \%$ hemicelluloses, $20 \%$ lignin, and $5 \%$ organic extractives are present [71]. Based on this composition of cellulose, hemicellulose and lignin, the woods are preferred as the feedstock for thermochemical conversion. The weight percentage of cellulose, hemicelluloses and lignin are recorded for different wood species like pine, eucalyptus globules [72], wheat straw, sorghum stalks [73], banana pseudostems [74] and bamboo [75]. Comparatively majority of the works are done on algae than woods due to the lesser yield of bio-oil from woods when it is processed under the temperature of 260 to 340 [76].

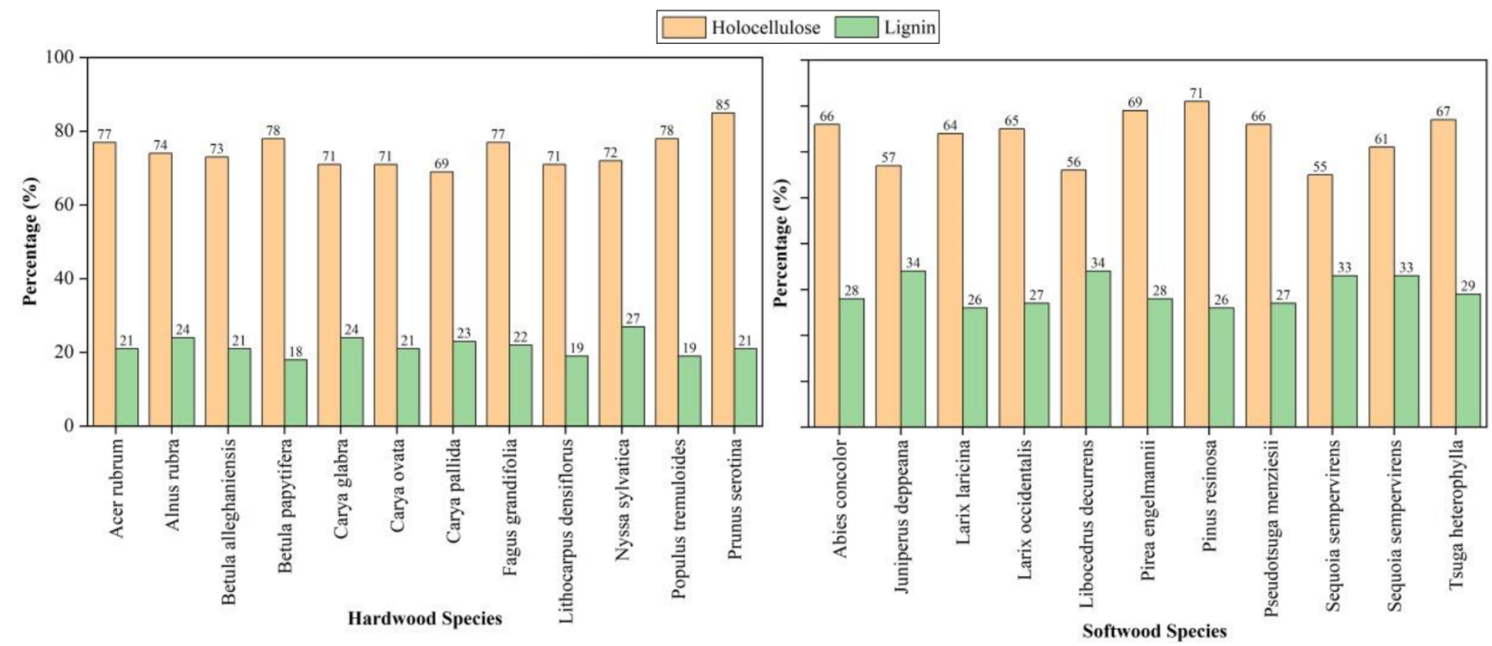

Fig. 3. Percentage of chemical constituents in hardwood species \& softwood species.

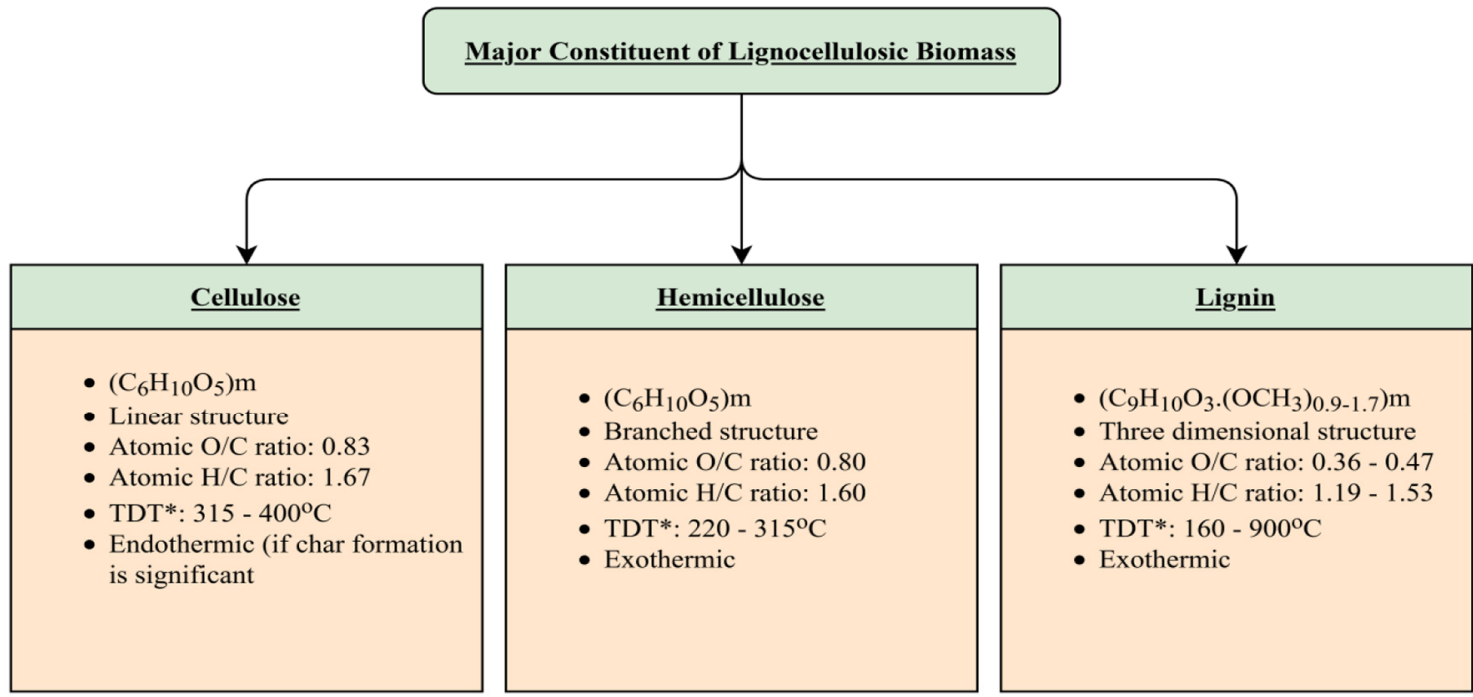

TDT - Thermal Decomposition Temperature

Fig. 4. Major constituent of lignocellulosic biomass. 


\subsection{Algal Biomass}

Algae are one of the versatile organisms without real stem and roots [77], that uses photosynthesis for growth and is chemically represented as [78]. These algae generally store the energy in cells using photosynthesis from where it can be extracted and used as the source for the fuel. The algae are broadly categorized as microalgae and macroalgae (commonly as seaweeds) based on the taxonomical group. The microalgae are single-celled organisms that are popularly called as blue-green algae that can be cultured in freshwaters. Despite being single cell, it is widely preferred as the source of renewable energy by hydrothermal treatment due to their growth condition, the requirement of simple resources like light, water, nutrients and source of carbon [79]. Cultivating and harvesting of these microalgae are simpler than any other biomass as they require ammonia, oxides of nitrogen and some phosphate groups which are commonly found in wastewaters. The algae harvested from wastewater is not suitable for food processing [80].

Meanwhile, the macroalgae are multicellular organism cultured not only in marine but also in the freshwater environment [67]. These macroalgae are categorized as brown macroalgae (Phaeophyta), green macroalgae (Chlorophyta) and red macroalgae (Rhodophyta) [77, 81].

These algae contain organic and aqueous phase with the primary chemical composition of proteins, carbohydrates, lipids and nucleic acids and these compositions vary with strains. Experiments (HTL (with and without catalyst) and supercritical fluids) were conducted on several algal biomasses and the yield percentage of biocrude, biogas and biochar are noted [82-85]. Along with the extraction of biocrude, production of biochar and biogas is also possible from these biomasses. For instant, the Fig. 5 shows the comparison between lignocellulosic biomass and algal biomass.

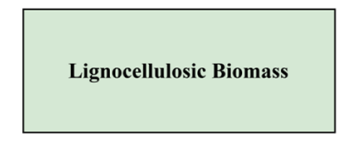

Algal Biomass (both micro \& macro)

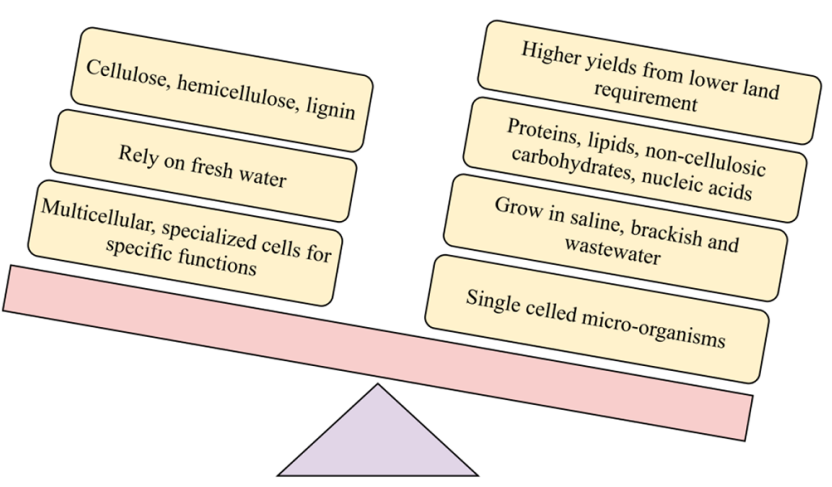

Fig. 5. Advantages of algal biomass over lignocellulosic biomass.

\subsection{Other Feedstocks}

Apart from algae, the aquatic plants like weeds such as watermeal, duckweeds, water hyacinth, water lettuce and some submerged plants like milfoil, hydrilla, curly-leaf pondweed are attracting many of the researchers recently [86]. In recent years usage of organic wastes like sludges from municipal wastewater treatment plants [87], cattle manure, swine manure [88], agricultural residues like corn straw, rice husk [89] as a source of feedstock in thermal depolymerisation activity is found increasing rapidly.

\section{HTL Mechanism in Lignocellulosic Biomass}

The major content of lignocellulosic biomass is cellulose, hemicellulose and lignin. The composition varies between each species and from the growing condition. The wood species and its corresponding compositions are given in the Fig. 3 for understanding. Many literatures states that when the concentration of cellulose and hemicellulose increases the bio-oil yield. While the lignin creates an alternate effect on bio-oil yield [90]. The hydrolysis pathway for lignocellulosic biomass occurs in the temperature range between 320 to $400^{\circ} \mathrm{C}$ and pressure rage between 10 to $15 \mathrm{MPa}$. High operating range in HTL causes dehydration reaction to occur that in turn remove oxygen atom in the form of water and carbon dioxide [91]. For example, in dehydration process saccharides undergo dehydration reaction to form hydroxymethylfurfural (HMF). During hydrolysis reaction, cellulose in lignocellulosic biomass hydrolyse rapidly into its corresponding monomers and oligomers. Hydrolysis reaction is followed by thermal decomposition, decomposition and deoxygenation which is also some major reactions. During HTL at subcritical point, the crystallinity of cellulose is decomposed by water [92]. Followed by cellulose decomposition hemicellulose decomposed to form monosaccharides and oligosaccharides [93]. In the extent of thermal degradation lignin is converted into phenolic group and many other chemicals.

\section{HTL Mechanism in Algal Biomass}

The constituents like proteins, carbohydrates, lipids are hydrolysed in the reactor to form different products. The peptide bond present in proteins is usually linked with two amino acid groups that form a polymer. During the hydrolysis, the peptide bond dissociates and produces the amino acids [94]. In liquefaction, apart from producing a lower yield of amino acids, they undergo decarboxylation and deamination producing amines, carbonic acid and another substituent like organic acid and ammonia [95]. On leaving the residue untouched over time, may get a chance of getting depolymerised to form lengthy chain hydrocarbons along with indole or pyrrole, which is an aromatic ring-type structure of phenols [96]. Next to protein, the major portion is occupied by lipids, which occurs naturally as an ester derivative of glycerol. Initially, these fatty acids present in algae biomass is in the form triacylglycerols (TAGs) which later hydrolysis to form glycerol. Under HTL condition, the glycerol produced during the hydrolysis process is transferred to acetaldehyde, methanol, acrolein, ethanol, allyl alcohol and propionaldehyde. The fatty acids are long-chain hydrocarbons with higher thermal stability and as apart from these, gases like $\mathrm{CO}, \mathrm{CO}_{2}$ and $\mathrm{H}_{2}$ comes out as the process progresses. The actual liquefaction process is to breakdown the carbohydrates into polar water-soluble organics as formic, acetic, lactic, benzene, 
Table 1. Various Algae Species with Its Major Constituents [97]

\begin{tabular}{|c|c|c|c|c|c|}
\hline Algae Strain & Size range $(\mathrm{mm})$ & Protein (\%) & Carbohydrates (\%) & Lipids (\%) & Nucleic acid (\%) \\
\hline Anabaena cylindrica & 4.3 & $43-56$ & $25-30$ & $04-71$ & - \\
\hline Chlamydomonas rheinhardii & 10 & 48 & 17 & 21 & - \\
\hline Chlorella pyrenoidosa & 10 & 57 & 26 & 2 & - \\
\hline Chlorella vulgaris & 6 & $51-58$ & $12-17$ & $14-22$ & 04-05 \\
\hline Dunaliella bioculata & 12 & 49 & 4 & 8 & - \\
\hline Dunaliella salina & 10 & 57 & 32 & 6 & - \\
\hline Euglena gracilis & 24 & $39-61$ & $14-18$ & $14-20$ & - \\
\hline Prymnesium parvum & 15 & $28-45$ & $25-33$ & $22-38$ & 01-02 \\
\hline Scenedesmus dimorphus & 4 & 08-18 & $21-52$ & $16-40$ & - \\
\hline Scenedesmus obliquus & 4 & $50-56$ & $09-17$ & $14-14$ & 03-06 \\
\hline Scenedesmus quadricauda & 18 & 47 & - & 1.9 & - \\
\hline Spirogyra sp. & 110 & $06-20$ & $33-64$ & $11-21$ & - \\
\hline Spirulina maxima & 12 & $60-71$ & $13-16$ & 06-71 & $03-4.5$ \\
\hline Spirulina platensis & 15 & 46 & 08-14 & 04-09 & 02-05 \\
\hline Synechoccus sp. & 1.6 & 63 & 15 & 11 & 5 \\
\hline Tetraselmis maculata & 14 & 52 & 15 & 3 & - \\
\hline
\end{tabular}

aldehydes and alcohols, since the carbohydrates cannot be directly converted to crude oil [21]. These algae contain organic and aqueous phase with the primary chemical composition of proteins, carbohydrates, lipids and nucleic acids and these compositions vary with strains that are shown in the below Table 1.

As it is known that the proteins, carbohydrates and lipids are the major components in the algal biomass, the above transformation processes, enhances the depolymerisation activity in the biomass and convert it to three different products such as biochar, bio-oil and biogas. Both the chemical and physical properties of all these three derivatives depend on feedstocks and the operating conditions like temperature, pressure, etc. Apart from the above-listed compounds, in algal conversion, other by-compounds are the algae derivatives, which are macropolymer of hydrocarbon which is insoluble in water and asphaltenes. The information over the derivatives of algae and asphaltenes are not available in larger numbers and hence these areas can be explored. However, during the depolymerisation activity that is at HTL condition $40 \%$ of carbon and $35 \%$ of hydrogen present in the feedstock are converted into oil [92]. On the other side other, than the compositions, other properties like volatile matter, ash, moisture, fixed carbon of algal biomass also play a significant role in conversion [98].

In HTL processes the wet biomass is converted into crude commonly referred to as bio-crude under the reasonable temperature and elevated pressure [92]. These crudes quality and quantity depends on different parameters such as feedstocks and its concentration, type of the process, holding time, heating rate, temperature and catalyst. These parameters have direct control over the recovered crude from the HTL process. Several attempts are made on these parameters to find out the optimal range for these parameters that are discussed below. But known works are not equipped to the satisfactory level. Since the process is operated under elevated temperature and pressure, the design of the equipment is a little difficult when comes in fabrication [99]. Generally, the thermochemical conversion occurs naturally in the subsurface of the earth where the kerogen (organic matter) gets depolymerised into hydrocarbons. But it takes prolonged time for the depolymerisation to occur completely. HTL is one of the major roles playing process in the conversion of biomass into the value-added products within a short time. The main difference in HTL than conventional thermal treatment is the usage of biomass in wet condition. It is because, in the conventional process such as pyrolysis and combustion, the moisture should be maintained in minimum level, roughly around 17 to 20 wt\% [100] whereas in HTL it can be of 80 wt\% [80].

\section{Effect of Different Parameters on the Yield of Bio-oil}

\subsection{Feedstock Composition}

Biomasses for HTL process varies with the composition based on the nature of the cultivated environment, nature of medium and nature of formation. So same species of biomass have different compositions when it is subjected to elementary analysis. Thus, the feedstocks collected from different landscapes have varied composition that largely affects the yield of bio-products. Various works in literature show the same kind of various in the product yield. From which it is clear that chemical composition of feedstock has an impact in the yield of both product and by-product [83].

\subsection{Elemental Composition}

Feedstocks and the biochar are subjected to elemental analysis to know the details of elemental carbon $(\mathrm{C})$, hydrogen $(\mathrm{H})$, nitrogen $(\mathrm{N})$, sulphur (S) and oxygen (O). Carbon is the largest and most significant constituent in any biomass. Both in woody and algal 
biomass, the source of carbon comes from the photosynthesis process and it is one of the major contributors for heating value. The nominal range of carbon in woody biomass is greater than $47.2 \%$, which is generally found minor in herbaceous. This is because compared to woody feedstock, herbaceous has reduced percentage of lignin [101]. Next to carbon, hydrogen exists in the form of carbohydrates and phenolic polymers in biomass. On heating, hydrogen creates the bond with free oxygen to form water that expressively helps in increasing the overall heating value. Nitrogen, which is considered as the backbone of any plant growth is supplied through fertilizers. On HTC condition, nitrogen doesn't get oxidised during the conversion rather it gets accumulated that helps in increasing the heating effect.

Sulphur is also one of the prime elements as it is hindered inside proteins and amino acids. Further, it is an essential nutrient for plant and algal growth. Compared to woody biomass, the herbaceous gathers higher sulphur concentration and it can be visualised from its growth. All biomass is rich in oxygen and it is gained by plants and algae through photosynthesis. Because of the excess content of oxygen, biocrude usage is limited in many applications. As like elemental analysis, it is important to examine molar element ratios $(\mathrm{H} / \mathrm{C}, \mathrm{O} / \mathrm{C}, \mathrm{N} / \mathrm{C})$ that result in answering the stoichiometric determination, degree of hydrogen unsaturated, comparison of unknowns and basic material characterization. $\mathrm{O} / \mathrm{C}$ relation shows the polarity and abundance of polar oxygen that contains the surface functional groups in biochar. And if the $\mathrm{O} / \mathrm{C}$ ratio is more, oxygen is more polar towards the functional group which sets up interest in heavy metal adsorption. Similarly, H/C relation shows aromatic nature and its stability of biochar, respectively.

\subsection{Solvent Polarity}

In many characteristic runs, selection of solvent is one of the important factors that determine the conversion rate. Biomass loading is the ratio of volume of the solvent (mL) to the weight of biomass (g). The solvent, both polar and non-polar solvents are also used for the extraction of oil from the oil-rich slurry. Polar solvents are the one that contains one $\mathrm{OH}$ polar group attached to a non-polar tail. In non-polar solvents, the molecules are evenly distributed and thus the dielectric constant is completely low. Observations are also made on the amount of solid content in the feedstock that directly affects the conversion percentage i.e higher ash content (solid-state particle) lower the bio-oil yield. The significance of solvent selection is analysed with different solvents like water, ethylene glycol, methanol, ethanol, n-propanol, isopropanol, acetone, ethyl acetate, 1,4-dioxane, tetraline and benzene. It is inferred that water, which is the polar solvent produces only minimal residue of $5.6 \%$ along with $43.8 \%$ of bio-oil and $16 \%$ of gas. Also, at HTL process conditions, nannochloropsis sp. with polar aprotic solvent (dichloromethane) yields the highest range of $35.1 \%$ of biocrude [102]. But ethanol significantly shows a higher percentage of yields with an increase in solid residue to an elevated value of $13.7 \%$ for a wide variety of biomasses [23, 103]. The effect of various solvents on the bio-oil yield is given below in the Table 2. Recently ionic liquids also play an effective role in increasing the yield of biocrude from biomass. Ionic liquids like 1-Butyl-3-methyl imidazolium methyl sulfate and 1-Ethyl-3-methyl imidazolium acetate expressions shows higher biocrude yield of $47 \%$ and $30 \%$ on chlorella vulgaris [104, 105].

\subsection{Catalyst}

Catalyst is one of the influencing parameters in the conversion of biomass to bioenergy. Both homogeneous and heterogeneous catalyst is used in the depolymerization process of biomass. Based on product requirement i.e. liquid fuel or gaseous fuel, the usage of catalyst varies widely. It is observed that the yield of bio-oil derived from Nannochloropsis $s p$. is higher when heterogeneous catalyst like Palladium on Carbon $(\mathrm{Pb} / \mathrm{C}), \mathrm{Ni} / \mathrm{SiO}_{2}-\mathrm{Al}_{2} \mathrm{O}_{3}$, Platinum on Carbon $(\mathrm{Pt} / \mathrm{C})$, Ruthium/Activated Charcoal $(\mathrm{Ru} / \mathrm{C}), \mathrm{CoMo} / \gamma-\mathrm{Al}_{2} \mathrm{O}_{3}$ (sulphide), and zeolite are used in the liquefaction process in absence of $\mathrm{H}_{2}$. But in the presence of $\mathrm{H}_{2}$, the heating value and bio-oil yield are highly insignificant despite the catalyst presence [124]. A similar study is made on Chlorella pyrenoidosaw with the catalyst that is mentioned above along with other combinations like HZSM-5 (Zeolite Socony Mobil-5), activated carbon, Raney-Ni (for denitrification) [125]. It is clear that alkalis (homogeneous catalyst) appear to be effective than organic acids that lead to an improvement in its heating value and yield, though, usage of the heterogeneous catalyst by various researchers shows a positive result in the biocrude yield [126-128]. More freshly, solid based catalyst $\left(\mathrm{CaO} / \mathrm{ZrO}_{2}\right)$ in 10 wt\% is used with the different solvent to improvise the compound selectivity and HHV value [129, 130].

\subsection{Biomass to Water Ratio}

The biomass to water ratio $(\mathrm{B} / \mathrm{W})$ is one of the key factors in the bio-crude production. The water present in the feedstock will be in the range of 70 to $80 \%$ [131]. Water acts as a reactant, solvent, catalyst which helps in degrading the biomass into the notable products. For HTL with high B/W ratio the extraction of lipids from the biomass is higher, since water is a denser solvent [132]. In contrast when $\mathrm{B} / \mathrm{W}$ is low the yield of the favourable product is lower than expected. At this condition the biomass and water cannot established well-mixed suspension results in poor reaction rates for liquefaction reaction, deamination, polymerization, etc. [133, 134]. The key effect of increase in B/W for beech wood, oak wood, aspen wood, Nanochloropsis sp., Spirulina platensis, Botryococcus braunii is reported. The $\mathrm{B} / \mathrm{W}$ ratio is also influenced by the other process parameters like temperature, pressure, residence time, etc. The presence of hydrogen in water attribute to stabilize the liquefaction and increases the yield of liquid fuels.

\subsection{Reaction Time}

The average reaction time for HTL is said to be 30 minutes, which are shown in literature yet it is not well-defined for all species of algae, lignocellulosic or other mixed feedstocks [125]. This depends on the reactor's material of construction because ample time is required for heat transfer. The reaction time is the tutor for the increase in liquid (biocrude) yield as it helps to hydrolysis with sufficient amount of $\mathrm{B} / \mathrm{W}$ ratio. It is also reported that energy recovery from the biomass varies with the difference in reaction time. As the impact of the rise in reaction time, the formation of water-insoluble products found increased, while the aqueous layer of biocrude is reduced in reasonable quantity [80, 114]. 
Table 2. Effect of Process Parameters on the Yield of Biocrude

\begin{tabular}{|c|c|c|c|c|c|c|c|c|c|}
\hline Feedstock & Type & Solvent used & $\begin{array}{c}\text { Bio-oil } \\
\text { Yield }\end{array}$ & $\begin{array}{l}\text { Temp. } \\
\text { (C) }\end{array}$ & $\begin{array}{l}\text { Pressure } \\
\text { (MPa) }\end{array}$ & $\begin{array}{c}\text { Bio-oil HHV } \\
\text { (MJ/kg) }\end{array}$ & Catalyst & $\begin{array}{c}\text { Nature of } \\
\text { catalyst }\end{array}$ & Ref. \\
\hline \multirow[t]{2}{*}{$\begin{array}{l}\text { Acacia mangium } \\
\text { wood }\end{array}$} & Wood & Acetone & $32 \%$ & 300 & 10 & 29.8 & $\begin{array}{l}\text { Sodium } \\
\text { carbonate }\end{array}$ & Homogeneous & [106] \\
\hline & & & $44 \%$ & 340 & 10 & 32.2 & $\begin{array}{l}\text { Potassium } \\
\text { carbonate }\end{array}$ & Homogeneous & \\
\hline \multirow[t]{2}{*}{ Aspen polar wood } & Wood & Diethyl ether & $54 \%$ & 340 & 10 & 36 & $\begin{array}{l}\text { Sodium } \\
\text { carbonate }\end{array}$ & Homogeneous & {$[107]$} \\
\hline & & & $36 \%$ & 340 & 10 & 34.1 & $\begin{array}{l}\text { Sodium } \\
\text { hydroxide }\end{array}$ & Heterogeneous & \\
\hline \multirow[t]{2}{*}{ Beech wood } & Wood & Water & $20 \%$ & 350 & 16.5 & 27.53 & Colemanite & Homogeneous & {$[108,109]$} \\
\hline & & & $36 \%$ & 300 & 9 & 29.8 & $\begin{array}{l}\text { Potassium } \\
\text { hydroxide }\end{array}$ & Heterogeneous & \\
\hline \multirow[t]{2}{*}{ Birchwood sawdust } & Wood & Water & $30 \%$ & 300 & 9 & 27.1 & $\begin{array}{l}\text { Magnesium } \\
\text { oxide }\end{array}$ & Heterogeneous & [110] \\
\hline & & & $40 \%$ & 300 & 9 & 26.3 & $\begin{array}{l}\text { Potassium } \\
\text { hydroxide }\end{array}$ & Heterogeneous & \\
\hline Ailanthus wood & Wood & Acetone & $29 \%$ & 303 & 11 & - & - & - & {$[101]$} \\
\hline Cypress wood & Wood & Diethyl ether & $15 \%$ & 300 & 8 & 26.3 & - & - & {$[111]$} \\
\hline Coconut shell & Agro residue & Acetone & $34 \%$ & 300 & 10 & 30.2 & $\begin{array}{l}\text { Sodium } \\
\text { carbonate }\end{array}$ & Homogeneous & {$[106]$} \\
\hline Bagasse pith & Agro residue & Acetone & $30 \%$ & 300 & 10 & 30.8 & $\begin{array}{l}\text { Sodium } \\
\text { carbonate }\end{array}$ & Homogeneous & {$[106]$} \\
\hline Coconut husk & Agro residue & Acetone & $28 \%$ & 300 & 10 & 29.8 & $\begin{array}{l}\text { Sodium } \\
\text { carbonate }\end{array}$ & Homogeneous & {$[106]$} \\
\hline Corn stalk & Agro residue & Acetone & $28 \%$ & 300 & 10 & 29.7 & $\begin{array}{l}\text { Sodium } \\
\text { carbonate }\end{array}$ & Homogeneous & [106] \\
\hline Hazelnut shell & Agro residue & Acetone & $28 \%$ & 303 & 11 & - & - & - & {$[101]$} \\
\hline Banana stem & Agro residue & Acetone & $21 \%$ & 300 & 10 & 32.9 & $\begin{array}{l}\text { Sodium } \\
\text { carbonate }\end{array}$ & Homogeneous & [106] \\
\hline Hazelnut seed coat & Agro residue & Acetone & $20 \%$ & 303 & 11 & - & - & - & {$[101]$} \\
\hline $\begin{array}{l}\text { Botryococcus } \\
\text { braunii }\end{array}$ & Algae & $\mathrm{DCM}$ & $58 \%$ & 300 & 10 & 47 & $\begin{array}{l}\text { Sodium } \\
\text { carbonate }\end{array}$ & Homogeneous & {$[112]$} \\
\hline $\begin{array}{l}\text { Nannochloropsis } \\
\text { salina }\end{array}$ & Algae & Acetone & $45 \%$ & 350 & 17.5 & 25.4 & - & - & [113] \\
\hline Chlorella & Algae & DCM & $42 \%$ & 350 & 25 & 33.8 & - & - & [114] \\
\hline $\begin{array}{l}\text { Dunaliella } \\
\text { tertiolecta }\end{array}$ & Algae & DCM & $37 \%$ & 300 & 10 & 36 & $\begin{array}{c}\text { Sodium } \\
\text { carbonate }\end{array}$ & Homogeneous & [106] \\
\hline Derbesia tenuissima & Algae & DCM & $33 \%$ & 340 & 25 & 33.2 & - & - & {$[84]$} \\
\hline Isochyrsis & Algae & Acetone & $40 \%$ & 350 & 20 & 34.18 & $\begin{array}{c}\text { Sodium } \\
\text { carbonate }\end{array}$ & Homogeneous & [115] \\
\hline Metroxylon sp. stem & Algae & Acetone & $29 \%$ & 300 & 10 & 28.1 & $\begin{array}{l}\text { Sodium } \\
\text { carbonate }\end{array}$ & Homogeneous & [106] \\
\hline $\begin{array}{l}\text { Cladophora } \\
\text { vagabunda }\end{array}$ & Algae & $\mathrm{DCM}$ & $28 \%$ & 340 & 25 & 15.1 & - & - & [116] \\
\hline $\begin{array}{l}\text { Metroxylon sp. } \\
\text { petioles }\end{array}$ & Algae & Acetone & $22 \%$ & 300 & 10 & 31 & $\begin{array}{l}\text { Sodium } \\
\text { carbonate }\end{array}$ & Homogeneous & [106] \\
\hline $\begin{array}{l}\text { Enteromorpha } \\
\text { prolifera }\end{array}$ & Algae & $\mathrm{DCM}$ & $23 \%$ & 290 & 30 & 29.5 & $\begin{array}{l}\text { Sulphuric } \\
\text { acid and } \\
\text { Acetic acid }\end{array}$ & Heterogeneous & [117] \\
\hline
\end{tabular}


Table 2. Continued

\begin{tabular}{|c|c|c|c|c|c|c|c|c|c|}
\hline Feedstock & Туре & Solvent used & $\begin{array}{c}\text { Bio-oil } \\
\text { Yield }\end{array}$ & $\begin{array}{l}\text { Temp. } \\
\text { (C) }\end{array}$ & $\begin{array}{c}\text { Pressure } \\
\text { (MPa) }\end{array}$ & $\begin{array}{c}\text { Bio-oil HHV } \\
\text { (MJ/kg) }\end{array}$ & Catalyst & $\begin{array}{c}\text { Nature of } \\
\text { catalyst }\end{array}$ & Ref. \\
\hline Tetraselmis sp. & Algae & DCM & $65 \%$ & 350 & 21 & 33.3 & - & - & [118] \\
\hline Dunaliella tertiolecta & Algae & Chloroform & $21 \%$ & 360 & 20 & 30.74 & $\begin{array}{c}\text { Sodium } \\
\text { carbonate }\end{array}$ & Homogeneous & [119] \\
\hline $\begin{array}{l}\text { Cladophora } \\
\text { coelothrix }\end{array}$ & Algae & DCM & $20 \%$ & 340 & 10 & 33.3 & - & - & {$[84]$} \\
\hline Chaetomorpha linum & Algae & DCM & $17 \%$ & 340 & 10 & 20.5 & - & - & {$[84]$} \\
\hline \multirow{15}{*}{ Nannochloropsis sp. } & \multirow{15}{*}{ Algae } & $\begin{array}{c}\text { Methoxy } \\
\text { cyclopentane }\end{array}$ & $31 \%$ & 350 & 22 & - & - & - & \\
\hline & & Hexane & $34 \%$ & 400 & 22 & - & - & - & \\
\hline & & Chloroform & $32 \%$ & 350 & 22 & - & - & - & \\
\hline & & DCM & $30 \%$ & 400 & 22 & 38 & - & - & \\
\hline & & Decane & $38 \%$ & 350 & 22 & - & - & - & \\
\hline & & Cyclohexane & $34 \%$ & 350 & 22 & - & - & - & \\
\hline & & Hexadecane & $37 \%$ & 350 & 22 & - & - & - & \\
\hline & & DCM & $58 \%$ & 350 & $\mathrm{HP}$ & 38.6 & $\mathrm{Pd} / \mathrm{C}$ & Heterogeneous & \multirow{8}{*}{$\begin{array}{c}{[102,120,} \\
121]\end{array}$} \\
\hline & & DCM & $50 \%$ & 350 & $\mathrm{HP}$ & 39.6 & $\mathrm{Pt} / \mathrm{C}$ & Heterogeneous & \\
\hline & & DCM & $52 \%$ & 350 & $\mathrm{HP}$ & 37.5 & $\mathrm{Ru} / \mathrm{C}$ & Heterogeneous & \\
\hline & & DCM & $53 \%$ & 350 & $\mathrm{HP}$ & 38.3 & $\begin{array}{c}\mathrm{Ni} / \\
\mathrm{SiO}_{2}-\mathrm{Al}_{2} \mathrm{O}_{3}\end{array}$ & Heterogeneous & \\
\hline & & DCM & $55 \%$ & 350 & $\mathrm{HP}$ & 38.8 & $\mathrm{CoMo} / \mathrm{Al}_{2} \mathrm{O}_{3}$ & Heterogeneous & \\
\hline & & DCM & $50 \%$ & 350 & $\mathrm{HP}$ & 35.4 & Zeolite & Heterogeneous & \\
\hline & & DCM & $22 \%$ & 350 & $\mathrm{HP}$ & 35.5 & Formic acid & Heterogeneous & \\
\hline & & DCM & $23 \%$ & 350 & $\mathrm{HP}$ & 39.1 & $\begin{array}{c}\text { Sodium } \\
\text { carbonate }\end{array}$ & Homogeneous & \\
\hline Spirulina & Algae & DCM & $33 \%$ & 300 & 12 & 33.2 & - & - & {$[122]$} \\
\hline Anaerobic sludge & Others & DCM & $9.4 \%$ & 300 & 12 & 32 & - & - & [122] \\
\hline Cattle manure & Others & DCM & $49 \%$ & 500 & 34.47 & 35.5 & - & - & [123] \\
\hline Garbage & Others & DCM & $21 \%$ & 340 & 18 & 36 & $\begin{array}{l}\text { Sodium } \\
\text { carbonate }\end{array}$ & Homogeneous & {$[106]$} \\
\hline Swine manure & Others & DCM & $31 \%$ & 300 & 12 & 34.7 & - & - & [122] \\
\hline
\end{tabular}

\subsection{Temperature and Pressure}

For liquefaction of biomass, temperature, heating rate and holdup time are the most important parameters. The precise operating temperature for HTL is found between 290 to 300 as wide array of experiments is carried out. Since the reaction is carried out at a subcritical temperature, with an increase in reaction temperature directly increases the bio-oil yield [135-137]. In the above-mentioned temperatures range, if the polarity of water molecules and organic phase increases, the yield of bio-oil is also found to increase [138, 139]. The deceptive colour of aqueous phase varies depending on the solubility the water and organic phases at the given temperature [140]. Sometimes, when the reaction temperature is raised above the favoured liquefaction temperature i.e above 350, it favours the polymerization reaction thus decreasing the yield of bio-oil $[141,142]$. Along with the temperature, the heating rate is an important parameter, but it is not widely studied in many works of literature. This is because it is impossible to maintain the same heating rate for wide temperature ranges. Only a few works of literature give detailed information about heating rate, yet its effect on the bio-oil yield is still indistinct [94]. Holdup time can be said as the maximum period for the biomass to get depolymerized in the reactor thermally, neglecting the heating or cooling time of the reactor. It is completely interlinked with temperature as it is shown in studies of Dunaliella tertiolecta by Toomoki et.al where the yield of bio-oil is $30.9 \%$ and $43.2 \%$ at 250 at different holding time like 5 and $60 \mathrm{~min}$ [106]. The temperature and pressure are interlinked parameters as the rise in temperature, pressure increases that can be usually observed from the pressure Vs temperature graph of a particular solvent. For complete conversion, the solvent present in the vessel should in sub-critical point as it ensures the solvent is in the liquid phase.

\section{8. $\mathrm{pH}$}

In any process, $\mathrm{pH}$ plays a significant role in the conversion of raw material into a product. It measures the nature of the solution whether it is acidic, basic or neutral. Sometimes in HTL, handling of the various aqueous solution along with the feedstock, it is important to understand the effect of $\mathrm{pH}$ on the conversion. This 
variation in $\mathrm{pH}$ is because of oxygenation and denitrification reactions that occur during the conversion [78]. Acidic range of feedstock shows a higher impact on the yield of bio-oil while the alkaline and neutral shows nearly the same yield [143]. The residual yield decreases for a dilute alkaline solution but the yield of water-soluble components increases for a concentrated alkaline solution [144]. The increases in the yield of water-soluble compounds make the oil to be high viscous which is difficult while handling.

\section{Product Identification and Separation}

The product obtained from the processing of biomass in liquefaction is majorly of liquefied high viscous crude. One challenge involved in the HTL of biomass is separating the organic layer from aqueous and residue. The solvents added should be immiscible and form two distinct layers but be capable of extracting volatile material. Generally, organic solvents such as dichloromethane, chloroform, acetone, toluene, decane and tetrahydrofuran are used for the separation of bio-oil. Yet solvents like dichloromethane, ethyl ether and diethyl ether are widely used because they are immiscible with aqueous solutions [145]. But solvents like tetrahydrofuran, acetone are completely miscible in aqueous solutions [117]. The selection also depends on the recycling character of solvent done using rotavapor or evaporator. It also has a straight impact on the extraction of bio-oil from the mixture and its percentage varies largely with the process. Likewise, it isn't meant that more volume of solvent should be used for the extraction. The separation of oil from the solvent is a little tedious since the bio-oil contains a considerable amount of lighter and volatile molecules. Because of this higher probability for the molecules to get evaporated along with the solvent during the separation from the oil-solvent mixture, thus affecting the oil yield. The general pathway to be followed for separation is given in the Fig. 6. Besides, the fraction of bio-oil from the aqueous phase, bio-oil yield and the energy recovery in the bio-oil [146] can be calculated as follows:

$$
\text { Bio }- \text { oil yield }=\frac{\text { Amount of bio-oil }}{\text { Amount of algae taken in the reactor }} \times 100 \%
$$

$$
\begin{aligned}
& \text { The fraction of total biooil from aqueous phase }= \\
& \frac{\text { Water-soluble products }}{\text { water-insoluble products }+ \text { Water soluble products }} \times 100 \% \\
& \text { Energy recovery of bio - oil }= \\
& \frac{\text { HHV of Bio-oil x Amount of bio-oil }}{\text { HHV of dry algae (initial) Mass of the algae feedstock }} \times 100 \%
\end{aligned}
$$

Since HTL bio-crude is derived from an organic material, it contains many oxygenated organic chemicals present including Nitrogenates, alkanes, phenolics, esters, ketones, aromatics and heterocyclics, aldehydes and carboxylic acids. Table S1 represents the various chemical groups, from biomass derived biocrude which is subjected to GC-MS.

\section{Conclusions}

The thermal depolymerisation stands in the larger area and HTL shows one of the promising technologies to produce biooil out of biomass. Other technologies such as pyrolysis, combustion, gasification, carbonization is highly explored and reached the saturation phase. On the other hand, HTL is the upraising technology that has various scope in the field of biofuels, producing value added chemical, etc. The prime advantage of using HTL technology is that it doesn't require any pretreatment process like mechanical, chemical or physico-chemical techniques. Since the pretreatment process is skipped in HTL, energy recovery is higher than other dry conversion process. The highlight of using biomass is that, lignocellulosic and algae biomass utilizes $\mathrm{CO}_{2}$, a greenhouse gas for their growth. Though the list elongates, the main challenge in HTL lies in mapping the complex chemical reaction pathways. From the above review, some key information and typical observations on process parameters during HTL are emphasized below:

- To maximise the yield of biocrude, the temperature must be placed near to the critical point of water.

- Longer residence time greater than $70 \mathrm{~min}$ leads to the decomposition of the biocrude.

- Addition of a catalyst to a certain level may increase the yield and improving the heating value of biocrude.

Although the above-mentioned results throw the light on HTL

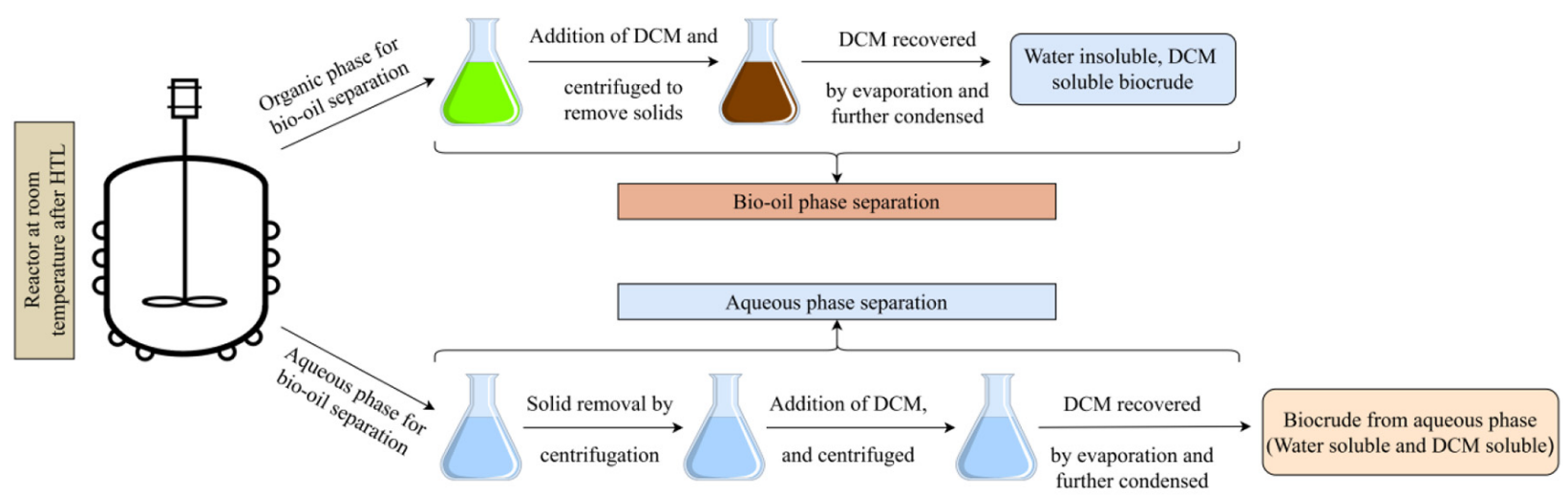

Fig. 6. Pathway for product (biocrude) separation. 
process and some areas remain unclear and it required detail research. Most of the data quoted are done in a batch/mini-scale operation (either stirred or non-stirred) but the main success is in scaling up the continuous operation. The separation and identification of desired products is crucial since it affects the nature of the biocrude and yield. The cells structure and composition in the biomass may change the process yield. The HTL oil shows the average yield percentage of 35 to $40 \mathrm{M} / \mathrm{kg}$ in associated with the maximum yield percentage of 85 to $80 \%$ (approx.). In addition, several publications show that the recovered oil has only minimal value of water content, oxygen and sulphur but the carbon recovery is about $70 \%$. So, it is loud and clear that recovered bio-oil is enriched with alkanes, nitrogenates and phenolic compounds. Such range of liquids has scope as biofuel and speciality chemicals.

In contrast the process also has its own setbacks such as operating conditions such as temperature, pressure and capital cost (widely differs based on the reactor type and material). HTL proves to be a breakthrough among the multiple technologies for the production of bio crude from various sources of biomass.

\section{Acknowledgements}

The authors express their gratitude to Department of Chemical Engineering, Kongu Engineering College, Perundurai, Erode, Dr. R.Vinu, Associate Professor, Department of Chemical Engineering, National Centre for Combustion Research and Development, Indian Institute of Technology Madras and Dr. B.Bharathiraja, Professor and Head, Chemical Engineering, Vel Tech High Tech Dr. Rangarajan, Chennai for their valuable support to carry out the above review. The authors also express their gratitude to undergraduate students L.C. Aravindhan, Kesav Prasath, Kirubakaran of 2017 to 2021 batch from the Department of Chemical Engineering, Kongu Engineering College, Perundurai, Erode.

\section{Author Contributions}

C.D.V. (Professor) devised the main conceptual ideas and revised the manuscript. S.R.R. (Assistant Professor) and M.S. (Assistant Professor) worked out almost all of the technical details, gathered data and wrote the manuscript.

\section{Reference}

1. McDonald RI, Mansur AV, Ascensão F, et al. Research gaps in knowledge of the impact of urban growth on biodiversity. Nat. Sustain. 2020;3:16-24.

2. Huang D, Zhou H, Lin L. Biodiesel: an alternative to conventional fuel. Energy Procedia 2012;16:1874-1885.

3. Shafie S, Al-attab K, Zainal Z. Effect of hydrothermal and vapothermal carbonization of wet biomass waste on bound moisture removal and combustion characteristics. Appl. Therm. Eng. 2018;139:187-195.

4. Tekin K, Karagöz S, Bektaş S. A review of hydrothermal biomass processing. Renew. Sust. Energ. Rev. 2014;40:673-687.
5. Zhou C-H, Xia X, Lin C-X, Tong D-S, Beltramini J. Catalytic conversion of lignocellulosic biomass to fine chemicals and fuels. Chem. Soc. Rev. 2011;40:5588-5617.

6. Li C, Yang X, Zhang Z, et al. Hydrothermal liquefaction of desert shrub Salix psammophila to high value-added chemicals and hydrochar with recycled processing water. Bio Resources 2013;8:2981-2997.

7. Wang Y, Liu Y, Yang W, Zhao Q, Dai Y. Evaluation of combustion properties and pollutant emission characteristics of blends of sewage sludge and biomass. Sci. Total Environ. 2020;720: 137365.

8. Stephen Gent MT, Christina Gerometta, Evan Almberg. Chapter Three - Fundamental Theories of Torrefaction by Thermochemical Conversion. In: Theoretical and Applied Aspects of Biomass Torrefaction: For Biofuels and Value-Added Products. Butterworth-Heinemann; 2017. p. 41-75.

9. Hicks KB, Montanti J, Nghiem NP. Chapter 11 - Use of barley grain and straw for biofuels and other industrial uses. In: American Associate of Cereal Chemists International, Barley (Second Edition). AACC International Press; 2014. p. 269-291.

10. Kirtania K. Chapter Four - Thermochemical Conversion Processes for Waste Biorefinery. In: Waste Biorefinery: Potential and Persepectives. Elsevier; 2018. p. 129-156.

11. Mohan SV, Rohit M, Subhash GV, et al. Chapter Twelve Algal oils as biodiesel, In: Biomass, Biofuels, Biochemicals, Biofuels from Algae (Second Edition). Elsevier; 2019. p. 287-323.

12. Kruse A, Bernolle P, Dahmen N, Dinjus E, Maniam P. Hydrothermal gasification of biomass: consecutive reactions to long-living intermediates. Energ. Environ. Sci. 2010;3:136-143.

13. Batidzirai B, Mignot A, Schakel W, Junginger H, Faaij A. Biomass torrefaction technology: Techno-economic status and future prospects. Energy 2013;62:196-214.

14. Velazquez-Lucio J, Rodríguez-Jasso RM, Colla LM, et al. Microalgal biomass pretreatment for bioethanol production: a review. Biofuel Res. J. 2018;5:780-791.

15. Briens C, Piskorz J, Berruti F. Biomass valorization for fuel and chemicals production-A review. Int. J. Chem. React. Eng. 2008;6.

16. Chen W-H, Kuo P-C. Torrefaction and co-torrefaction characterization of hemicellulose, cellulose and lignin as well as torrefaction of some basic constituents in biomass. Energy 2011;36:803-811.

17. Du S-W, Chen W-H, Lucas JA. Pulverized coal burnout in blast furnace simulated by a drop tube furnace. Energy 2010;35:576-581.

18. Parikh J, Channiwala S, Ghosal G. A correlation for calculating HHV from proximate analysis of solid fuels. Fuel 2005;84: 487-494.

19. Chen D, Gao A, Cen K, Zhang J, Cao X, Ma Z. Investigation of biomass torrefaction based on three major components: Hemicellulose, cellulose, and lignin. Energy Convers. Manage. 2018;169:228-237.

20. Zhang C, Ho S-H, Chen W-H, Xie Y, Liu Z, Chang J-S. Torrefaction performance and energy usage of biomass wastes and their correlations with torrefaction severity index. Appl. Energ. 2018;220:598-604.

21. Zhang C, Ho S-H, Chen W-H, Fu Y, Chang J-S, Bi X. Oxidative 
torrefaction of biomass nutshells: Evaluations of energy efficiency as well as biochar transportation and storage. Appl. Energ. 2019;235:428-441.

22. Chen W-H. Chapter 10 - Torrefaction, in Pretreatment of Biomass, A Pandey, Editors. Amsterdam; 2015. p. 173-192.

23. Chen W-H, Lin B-J, Huang M-Y, Chang J-S. Thermochemical conversion of microalgal biomass into biofuels: a review. Bioresour. Technol. 2015;184:314-327.

24. Ye-Ebiyo Y, Kitaw Y, Girma S, Desta H, Seyoum A, Teklehaimanot A. Study on health extension workers: access to information, continuing education and reference materials. The Ethiop. J. Health Dev. 2007;21:240-245.

25. Novak J, Johnson MG. Chapter 3 - Elemental and Spectroscopic Characterization of Low-Temperature $\left(350^{\circ} \mathrm{C}\right)$ Lignocellulosicand Manure-Based Designer Biochars and Their Use as Soil Amendments. In: Biochar from Biomass and Waste. Elsevier; 2019. p. 37-58.

26. Jenkins R, Sutton A, Robichaud D. Chapter 8 - Pyrolysis of Biomass for Aviation Fuel, in Biofuels for Aviation: Feedstocks, Technology and Implementation. 2016. p. 191-215.

27. Bu Q, Lei H, Ren S, et al. Phenol and phenolics from lignocellulosic biomass by catalytic microwave pyrolysis. Bioresour. Technol. 2011;102:7004-7007.

28. Garcia-Perez M, Chaala A, Pakdel H, Kretschmer D, Roy C. Vacuum pyrolysis of softwood and hardwood biomass: comparison between product yields and bio-oil properties. J. Anal. App. Pyrol. 2007;78:104-116.

29. Krieger-Brockett B. Microwave pyrolysis of biomass. Res. Chem. Intermediat. 1994;20:39-49.

30. Dabros TM, Stummann MZ, Høj M, et al. Transportation fuels from biomass fast pyrolysis, catalytic hydrodeoxygenation, and catalytic fast hydropyrolysis. Prog. Energy Combust. Sci. 2018;68:268-309.

31. Ruan R, Zhang Y, Chen P, et al. Biofuels: introduction, in Biofuels: Alternative feedstocks and conversion processes for the production of liquid and gaseous biofuels. 2019. p. 3-43.

32. Zhang Y, Chen P, Liu S, et al. Effects of feedstock characteristics on microwave-assisted pyrolysis-a review. Bioresour. Technol. 2017;230:143-151.

33. Bundhoo ZM. Microwave-assisted conversion of biomass and waste materials to biofuels. Renew. Sust. Energ. Rev. 2018;82: 1149-1177.

34. Fonts I, Gea G, Azuara M, Ábrego J, Arauzo J. Sewage sludge pyrolysis for liquid production: a review. Renew. Sust. Energy Rev. 2012;16:2781-2805.

35. Al Arni S. Comparison of slow and fast pyrolysis for converting biomass into fuel. Renew. Energ. 2018;124:197-201.

36. El Hanandeh A. Energy recovery alternatives for the sustainable management of olive oil industry waste in Australia: life cycle assessment. J. Clean. Prod. 2015;91:78-88.

37. Duman G, Uddin MA, Yanik J. Hydrogen production from algal biomass via steam gasification. Bioresour. Technol. 2014;166: 24-30.

38. Onwudili JA, Lea-Langton AR, Ross AB, Williams PT. Catalytic hydrothermal gasification of algae for hydrogen production: composition of reaction products and potential for nutrient recycling. Bioresour. Technol. 2013;127:72-80.
39. Guan Q, Wei C, Savage PE. Kinetic model for supercritical water gasification of algae. Phys. Chem. Chem. Phys. 2012;14: 3140-3147.

40. Limousy L, Jeguirim M, Labaki M. Chapter 11 - Energy applications of coffee processing by-products. In: Handbook of Coffee Processing By-Products. Academic Press; 2017. p. 323-367.

41. de Oliveira JL, da Silva JN, Pereira EG, Oliveira Filho D, Carvalho DR. Characterization and mapping of waste from coffee and eucalyptus production in Brazil for thermochemical conversion of energy via gasification. Renew. Sust. Energ. Rev. 2013;21: $52-58$.

42. Lamers P, Junginger M, Hamelinck C, Faaij A. Developments in international solid biofuel trade-An analysis of volumes, policies, and market factors. Renew. Sust. Energ. Rev. 2012;16:3176-3199.

43. Kumar S, Ankaram S. Chapter 12 - Waste-to-Energy Model/Tool Presentation. In: Current Developments in Biotechnology Bioengineering. Elsevier; 2019. p. 239-258.

44. Biller P, Ross A. Production of biofuels via hydrothermal conversion. In: Handbook of Biofuels Production (Second Edition). Woodhead Publishing; 2016. p. 509-547.

45. Biswas B, Kumar J, Bhaskar T. Advanced hydrothermal liquefaction of biomass for bio-oil production. In: Biomass, Biofuels, Biochemicals, Biofuels: Alternative Feedstocks and Conversion Processes for the Production of Liquid and Gaseous Biofuels (Second Edition). Academic Press; 2019. p. 245-266.

46. Funke A, Ziegler F. Hydrothermal carbonization of biomass: a summary and discussion of chemical mechanisms for process engineering. Biofuel. Biopro. Bior. 2010;4:160-177.

47. Oliveira I, Blöhse D, Ramke H-G. Hydrothermal carbonization of agricultural residues. Bioresour. Technol. 2013;142:138-146.

48. Hoekman SK, Broch A, Robbins C, Zielinska B, Felix L. Hydrothermal carbonization (HTC) of selected woody and herbaceous biomass feedstocks. Biomass. Con. Bior. 2013;3: 113-126.

49. Broch A, Jena U, Hoekman SK, Langford J. Analysis of solid and aqueous phase products from hydrothermal carbonization of whole and lipid-extracted algae. Energies 2014;7:62-79.

50. Park KY, Lee K, Kim D. Characterized hydrochar of algal biomass for producing solid fuel through hydrothermal carbonization. Bioresour. Technol. 2018;258:119-124.

51. Wei J, Liu Y, Li J, Zhu Y, Yu H, Peng Y. Adsorption and co-adsorption of tetracycline and doxycycline by one-step synthesized iron loaded sludge biochar. Chemosphere 2019;236:124254.

52. Yu H, Zou W, Chen J, et al. Biochar amendment improves crop production in problem soils: A review. J. Environ Manage. 2019;232:8-21.

53. Zhang H, Xue G, Chen H, Li X. Magnetic biochar catalyst derived from biological sludge and ferric sludge using hydrothermal carbonization: preparation, characterization and its circulation in Fenton process for dyeing wastewater treatment. Chemosphere 2018;191:64-71.

54. Do Minh T, Song J, Deb A, Cha L, Srivastava V, Sillanpää M. Biochar based catalysts for the abatement of emerging pollutants: A review. Chem. Eng. J. 2020;124856.

55. Behrendt F, Neubauer Y, Oevermann M, Wilmes B, Zobel N. Direct liquefaction of biomass. Chem. Eng. Tec. 2008;31:667-677. 
56. Gu Y, Zhang X, Deal B, Han L. Biological systems for treatment and valorization of wastewater generated from hydrothermal liquefaction of biomass and systems thinking: A review. Bioresour. Technol. 2019;278:329-345.

57. Gollakota A, Savage PE. Fast and Isothermal Hydrothermal Liquefaction of Polysaccharide Feedstocks. ACS Sustain. Chem. Eng. 2020;8:3762-3772.

58. Monlau F, Sambusiti C, Barakat A, et al. Do furanic and phenolic compounds of lignocellulosic and algae biomass hydrolyzate inhibit anaerobic mixed cultures? A comprehensive review. Biotechnol. Adv. 2014;32:934-951.

59. Fasolini A, Cucciniello R, Paone E, Mauriello F, Tabanelli T. A Short Overview on the Hydrogen Production Via Aqueous Phase Reforming (APR) of Cellulose, C6-C5 Sugars and Polyols. Catalysts 2019;9:917.

60. Kundu K, Chatterjee A, Bhattacharyya T, Roy M, Kaur A. Thermochemical Conversion of Biomass to Bioenergy A Review. In: Singh A., Agarwal R., Agarwal A., Dhar A., Shukla M, eds. Prospects of Alternative Transportation Fuels. Energy, Environment, and Sustainability. Singapore: Springer; 2018. p. 235-268.

61. Kumar M, Oyedun AO, Kumar A. A review on the current status of various hydrothermal technologies on biomass feedstock. Renew. Sust. Energ. Rev. 2018;81:1742-1770.

62. Sztancs G, Juhasz L, Nagy BJ, et al. Co-Hydrothermal gasification of Chlorella vulgaris and hydrochar: The effects of waste-to-solid biofuel production and blending concentration on biogas generation. Bioresour. Technol. 2020;122793.

63. Matsumura Y. Chapter 9 - Hydrothermal gasification of biomass. In: Ashok Pandey, Thallada Bhaskar, Michael Stöcker, Rajeev K. Sukumaran, eds. Recent Advances in Thermo-Chemical Conversion of Biomass. Elsevier; 2015. p. 251-267.

64. Toor SS, Reddy H, Deng S, et al. Hydrothermal liquefaction of Spirulina and Nannochloropsis salina under subcritical and supercritical water conditions. Bioresour. Technol. 2013;131: 413-419.

65. Morgan JW, Shalen PB. Valuations, trees, and degenerations of hyperbolic structures. I. Ann. Math. 1984;120:401-476.

66. Demirbas A. Estimating of structural composition of wood and non-wood biomass samples. Energ. Source. 2005;27:761-767.

67. Abraham A, Mathew AK, Park H, et al. Pretreatment strategies for enhanced biogas production from lignocellulosic biomass. Bioresour. Technol. 2020;301:122725.

68. Cocero MJ. Supercritical water processes: Future prospects. J. Supercrit. Fluid. 2018;134:124-132.

69. Lisý M, Lisá H, Jecha D, Baláš M, Križan P. Characteristic Properties of Alternative Biomass Fuels. Energies 2020;13:1448.

70. Channiwala S, Parikh P. A unified correlation for estimating HHV of solid, liquid and gaseous fuels. Fuel 2002;81:1051-1063.

71. Peng J, Bi XT, Lim J, Sokhansanj S. Development of torrefaction kinetics for British Columbia softwoods. Int. J. Chem. React. Eng. 2012;10:

72. Jiménez L, Rodríguez A, Pérez A, Moral A, Serrano L. Alternative raw materials and pulping process using clean technologies. Ind. Crop. prod. 2008;28:11-16.

73. Dar RA, Dar EA, Kaur A, Phutela UG. Sweet sorghum-a promising alternative feedstock for biofuel production. Renew. Sust. Energ.
Rev. 2018;82:4070-4090.

74. Cordeiro N, Faria M, Abraham E, Pothan LA. Assessment of the changes in the cellulosic surface of micro and nano banana fibres due to saponin treatment. Carbohyd. Polym. 2013;98: 1065-1071.

75. Suhara H, Kodama S, Kamei I, Maekawa N, Meguro S. Screening of selective lignin-degrading basidiomycetes and biological pretreatment for enzymatic hydrolysis of bamboo culms. Int. Biodeter. Biodegr. 2012;75:176-180.

76. Liu Y, Yuan X-z, Huang H-j, Wang X-l, Wang H, Zeng G-m. Thermochemical liquefaction of rice husk for bio-oil production in mixed solvent (ethanol-water). Fuel process. Technol. 2013;112:93-99.

77. Milledge JJ, Harvey PJ. Potential process 'hurdles' in the use of macroalgae as feedstock for biofuel production in the British Isles. J. Chem. Technol. Biot. 2016;91:2221-2234.

78. Du Y, Sun J, Gong Q, Wang Y, Fu P, Zhu W. New $\alpha$-pyridones with quorum-sensing inhibitory activity from diversity-enhanced extracts of a Streptomyces sp. derived from marine algae. J. Agr. Food Chem. 2018;66:1807-1812.

79. Garcia Alba L, Torri C, Samorì C, et al. Hydrothermal treatment (HTT) of microalgae: evaluation of the process as conversion method in an algae biorefinery concept. Energ. Fuel. 2011;26:642-657.

80. Barreiro DL, Prins W, Ronsse F, Brilman W. Hydrothermal liquefaction (HTL) of microalgae for biofuel production: state of the art review and future prospects. Biomass Bioenerg. 2013;53:113-127.

81. Beacham TA, Sweet JB, Allen MJ. Large scale cultivation of genetically modified microalgae: A new era for environmental risk assessment. Algal Res. 2017;25:90-100.

82. Anastasakis K, Ross A. Hydrothermal liquefaction of four brown macro-algae commonly found on the UK coasts: An energetic analysis of the process and comparison with bio-chemical conversion methods. Fuel 2015;139:546-553.

83. Vardon DR, Sharma BK, Scott J, et al. Chemical properties of biocrude oil from the hydrothermal liquefaction of Spirulina algae, swine manure, and digested anaerobic sludge. Bioresour. Technol. 2011;102:8295-8303.

84. Neveux N, Yuen A, Jazrawi C, et al. Biocrude yield and productivity from the hydrothermal liquefaction of marine and freshwater green macroalgae. Bioresour. Technol. 2014;155: 334-341.

85. Díaz-Vázquez LM, Rojas-Pérez A, Fuentes-Caraballo M, Robles IV, Jena U, Das K. Demineralization of Sargassum spp. macroalgae biomass: selective hydrothermal liquefaction process for bio-oil production. Front. Energ. Res. 2015;3:6.

86. Wang F, Tian Y, Zhang C-C, Xu Y-P, Duan P-G. Hydrotreatment of bio-oil distillates produced from pyrolysis and hydrothermal liquefaction of duckweed: a comparison study. Sci. Total Environ. 2018;636:953-962.

87. He C, Giannis A, Wang J-Y. Conversion of sewage sludge to clean solid fuel using hydrothermal carbonization: hydrochar fuel characteristics and combustion behavior. Appl. Energ. 2013;111:257-266.

88. Mohan D, Sarswat A, Ok YS, Pittman Jr CU. Organic and inorganic contaminants removal from water with biochar, a renew- 
able, low cost and sustainable adsorbent-a critical review. Bioresour. Technol. 2014;160:191-202.

89. Chen X, Chen G, Chen L, et al. Adsorption of copper and zinc by biochars produced from pyrolysis of hardwood and corn straw in aqueous solution. Bioresour. Technol. 2011;102: 8877-8884.

90. Bhaskar T, Sera A, Muto A, Sakata Y. Hydrothermal upgrading of wood biomass: influence of the addition of $\mathrm{K} 2 \mathrm{CO} 3$ and cellulose/lignin ratio. Fuel 2008;87:2236-2242.

91. Shuai L, Luterbacher J. Organic solvent effects in biomass conversion reactions. Chem. Sus. Chem. 2016;9:133-155.

92. Akhtar J, Amin NAS. A review on process conditions for optimum bio-oil yield in hydrothermal liquefaction of biomass. Renew. Sust. Energ. Rev. 2011;15:1615-1624.

93. Gao Y, Wang H, Guo J, Peng P, Zhai M, She D. Hydrothermal degradation of hemicelluloses from triploid poplar in hot compressed water at $180-340^{\circ}$ C. Polym. Degrad. Stabil. 2016;126: 179-187.

94. Biller P, Ross A. Potential yields and properties of oil from the hydrothermal liquefaction of microalgae with different biochemical content. Bioresour. Technol. 2011;102:215-225.

95. Toor SS, Rosendahl L, Rudolf A. Hydrothermal liquefaction of biomass: a review of subcritical water technologies. Energy 2011;36:2328-2342.

96. Akiya N, Savage PE. Roles of water for chemical reactions in high-temperature water. Chem. Rev. 2002;102:2725-2750.

97. Akhtar J, Amin NAS. A review on process conditions for optimum bio-oil yield in hydrothermal liquefaction of biomass. Renew. Sust. Energ. Rev. 2011;15:1615-1624.

98. Biller P, Sharma BK, Kunwar B, Ross AB. Hydroprocessing of bio-crude from continuous hydrothermal liquefaction of microalgae. Fuel 2015;159:197-205.

99. Ranganathan P, Savithri S. Computational Fluid Dynamics simulation of hydrothermal liquefaction of microalgae in a continuous plug-flow reactor. Bioresour. Technol. 2018;258: 151-157.

100. Raclavská H, Corsaro A, Hlavsová A, Juchelková D, Zajonc O. The effect of moisture on the release and enrichment of heavy metals during pyrolysis of municipal solid waste. Waste Manage. Res. 2015;33:267-274.

101. Demirbaş A. Effect of lignin content on aqueous liquefaction products of biomass. Energ. Convers. Manage. 2000;41:1601-1607.

102. Jiang J, Savage PE. Using Solvents To Reduce the Metal Content in Crude Bio-oil from Hydrothermal Liquefaction of Microalgae. Ind. Eng. Chem. Res. 2019;58:22488-22496.

103. Duan P, Jin B, Xu Y, et al. Thermo-chemical conversion of Chlorella pyrenoidosa to liquid biofuels. Bioresour. Technol. 2013;133:197-205.

104. Choi S-A, Oh Y-K, Jeong M-J, Kim SW, Lee J-S, Park J-Y. Effects of ionic liquid mixtures on lipid extraction from Chlorella vulgaris. Renew. Energ. 2014;65:169-174.

105. Kim Y-H, Park S, Kim MH, et al. Ultrasound-assisted extraction of lipids from Chlorella vulgaris using [Bmim][MeSO4]. Biomass Bioenerg. 2013;56:99-103.

106. Minowa T, Yokoyama S-y, Kishimoto M, Okakura T. Oil production from algal cells of Dunaliella tertiolecta by direct thermochemical liquefaction. Fuel 1995;74:1735-1738.
107. Eager RL, Mathews JF, Pepper JM, Zohdi H. Studies on the products resulting from the conversion of aspen poplar to an oil. Can. J. Chem. 1981;59:2191-2198.

108. Tekin K, Karagöz S, Bektaş S. Hydrothermal liquefaction of beech wood using a natural calcium borate mineral. $J$. Supercrit. Fluid. 2012;72:134-139.

109. Liu H-M, Li M-F, Yang S, Sun R-C. Understanding the mechanism of cypress liquefaction in hot-compressed water through characterization of solid residues. Energies 2013;6:1590-1603.

110. Nazari L, Yuan Z, Souzanchi S, Ray MB, Xu CC. Hydrothermal liquefaction of woody biomass in hot-compressed water: catalyst screening and comprehensive characterization of bio-crude oils. Fuel 2015;162:74-83.

111. Yin S, Mehrotra AK, Tan Z. Alkaline hydrothermal conversion of cellulose to bio-oil: influence of alkalinity on reaction pathway change. Bioresour. Technol. 2011;102:6605-6610.

112. Dote Y, Sawayama S, Inoue S, Minowa T, Yokoyama S-y. Recovery of liquid fuel from hydrocarbon-rich microalgae by thermochemical liquefaction. Fuel 1994;73:1855-1857.

113. Toor SS, Reddy H, Deng S, et al. Hydrothermal liquefaction of Spirulina and Nannochloropsis salina under subcritical and supercritical water conditions. Bioresour. Technol. 2013;131:413-419.

114. Jazrawi C, Biller P, Ross AB, Montoya A, Maschmeyer T, Haynes BS. Pilot plant testing of continuous hydrothermal liquefaction of microalgae. Algal. Res. 2013;2:268-277.

115. Shakya R, Whelen J, Adhikari S, Mahadevan R, Neupane $\mathrm{S}$. Effect of temperature and $\mathrm{Na}_{2} \mathrm{CO}_{3}$ catalyst on hydrothermal liquefaction of algae. Algal. Res. 2015;12:80-90.

116. Neveux N, Yuen AK, Jazrawi C, et al. Biocrude yield and productivity from the hydrothermal liquefaction of marine and freshwater green macroalgae. Bioresour. Technol. 2014;155:334-341.

117. Yang W, Li X, Liu S, Feng L. Direct hydrothermal liquefaction of undried macroalgae Enteromorpha prolifera using acid catalysts. Energy Convers. Manage. 2014;87:938-945.

118. Han Y, Hoekman SK, Cui Z, Jena U, Das P. Hydrothermal liquefaction of marine microalgae biomass using co-solvents. Algal. Res. 2019;38:101421.

119. Shuping Z, Yulong W, Mingde Y, Kaleem I, Chun L, Tong J. Production and characterization of bio-oil from hydrothermal liquefaction of microalgae Dunaliella tertiolecta cake. Energy 2010;35:5406-5411.

120. Valdez PJ, Dickinson JG, Savage PE. Characterization of product fractions from hydrothermal liquefaction of Nannochloropsis sp. and the influence of solvents. Energ. Fuel. 2011;25:3235-3243.

121. Duan P, Savage PE. Hydrothermal Liquefaction of a Microalga with Heterogeneous Catalysts. Ind. Eng. Chem. Res. 2011;50:52-61.

122. Vardon DR, Sharma BK, Scott J, et al. Chemical properties of biocrude oil from the hydrothermal liquefaction of Spirulina algae, swine manure, and digested anaerobic sludge. Bioresour. Technol. 2011;102:8295-8303.

123. Yin S, Dolan R, Harris M, Tan Z. Subcritical hydrothermal liquefaction of cattle manure to bio-oil: Effects of conversion parameters on bio-oil yield and characterization of bio-oil. 
Bioresour. Technol. 2010;101:3657-3664.

124. Duan P, Savage PE. Hydrothermal liquefaction of a microalga with heterogeneous catalysts. Ind. Eng. Chem. Res. 2010;50: 52-61.

125. Bai X, Duan P, Xu Y, Zhang A, Savage PE. Hydrothermal catalytic processing of pretreated algal oil: A catalyst screening study. Fuel 2014;120:141-149.

126. Christensen PR, Mørup AJ, Mamakhel A, Glasius M, Becker J, Iversen BB. Effects of heterogeneous catalyst in hydrothermal liquefaction of dried distillers grains with solubles. Fuel 2014;123:158-166.

127. Zhang J, Chen W-T, Zhang P, Luo Z, Zhang Y. Hydrothermal liquefaction of Chlorella pyrenoidosa in sub-and supercritical ethanol with heterogeneous catalysts. Bioresour. Technol. 2013;133:389-397.

128. Rojas-Pérez A, Diaz-Diestra D, Frias-Flores CB, et al. Catalytic effect of ultrananocrystalline Fe $3 \mathrm{O} 4$ on algal bio-crude production via HTL process. Nanoscale 2015;7:17664-17671.

129. Biswas B, Kumar A, Fernandes AC, et al. Solid base catalytic hydrothermal liquefaction of macroalgae: effects of process parameter on product yield and characterization. Bioresour. Technol. 2020;123232.

130. Cheng F, Tompsett GA, Murphy CM, et al. Synergistic Effects of Inexpensive Mixed Metal Oxides for Catalytic Hydrothermal Liquefaction of Food Wastes. ACS Sustain. Chem. Eng. 2020;8:6877-6886.

131. Derek RV, Brajendra KS, Grant VB, Kishore R, Timothy JS. Thermochemical conversion of raw and defatted algal biomass via hydrothermal liquefaction and slow pyrolysis. Bioresour. Technol. 2012;109:178-187.

132. Jindal MK, Jha MK. Effect of process parameters on hydrothermal liquefaction of waste furniture sawdust for bio-oil production. RSC Adv. 2016;6:41772-41780.

133. Karagöz S, Bhaskar T, Muto A, Sakata Y. Hydrothermal upgrading of biomass: Effect of $\mathrm{K} 2 \mathrm{CO} 3$ concentration and biomass/water ratio on products distribution. Bioresour. Technol. 2006;97:90-98.

134. Tzanetis KF, Posada JA, Ramirez A. Analysis of biomass hydrothermal liquefaction and biocrude-oil upgrading for renewable jet fuel production: The impact of reaction conditions on production costs and GHG emissions performance. Renew. Energ. 2017;113:1388-1398.

135. Valdez PJ, Tocco VJ, Savage PE. A general kinetic model for the hydrothermal liquefaction of microalgae. Bioresour. Technol. 2014;163:123-127.

136. Miao C, Chakraborty M, Dong T, Yu X, Chi Z, Chen S. Sequential hydrothermal fractionation of yeast Cryptococcus curvatus biomass. Bioresour. Technol. 2014;164:106-112.

137. Miao C, Chakraborty M, Chen S. Impact of reaction conditions on the simultaneous production of polysaccharides and bio-oil from heterotrophically grown Chlorella sorokiniana by a unique sequential hydrothermal liquefaction process. Bioresour. Technol. 2012;110:617-627.

138. Kruse A, Maniam P, Spieler F. Influence of proteins on the hydrothermal gasification and liquefaction of biomass. 2 . Model compounds. Ind. Eng. Chem. Res. 2007;46:87-96.

139. Christensen PS, Peng Gl, Vogel Fdr, Iversen BB. Hydrothermal liquefaction of the microalgae Phaeodactylum tricornutum: impact of reaction conditions on product and elemental distribution. Energ. Fuel. 2014;28:5792-5803.

140. Peng X, Ma X, Lin Y, Wang X, Zhang X, Yang C. Effect of process parameters on solvolysis liquefaction of Chlorella pyrenoidosa in ethanol-water system and energy evaluation. Energ. Convers. Manage. 2016;117:43-53.

141. Yang J-H, Shin H-Y, Ryu Y-J, Lee C-G. Hydrothermal liquefaction of Chlorella vulgaris: Effect of reaction temperature and time on energy recovery and nutrient recovery. J. Ind. Eng. Chem. 2018;68:267-273.

142. Faeth JL, Valdez PJ, Savage PE. Fast hydrothermal liquefaction of Nannochloropsis sp. to produce biocrude. Energ. Fuel. 2013;27:1391-1398.

143. Yin S, Tan Z. Hydrothermal liquefaction of cellulose to bio-oil under acidic, neutral and alkaline conditions. Appl. Energ. 2012;92:234-239.

144. Sugano M, Takagi H, Hirano K, Mashimo K. Hydrothermal liquefaction of plantation biomass with two kinds of wastewater from paper industry. J. Mater. Sci. 2008;43:2476-2486.

145. Anastasakis K, Ross A. Hydrothermal liquefaction of the brown macro-alga Laminaria Saccharina: Effect of reaction conditions on product distribution and composition. Bioresour. Technol. 2011;102:4876-4883.

146. Sheng L, Wang X, Yang X. Prediction model of biocrude yield and nitrogen heterocyclic compounds analysis by hydrothermal liquefaction of microalgae with model compounds. Bioresour. Technol. 2018;247:14-20. 